\title{
House Prices, Mortgage Debt Dynamics and Economic Fluctuations in France: A Semi-Structural Approach ${ }^{1}$
}

\section{Guillaume Bove ${ }^{2}$, Stéphane Dees ${ }^{3}$ and Camille Thubin ${ }^{4}$}

\section{Decembre 2020, WP \#787}

\begin{abstract}
We develop a model of house prices and household indebtedness and include it in the Banque de France's semi-structural macroeconomic model in order to analyse the implications of mortgage debt dynamics on economic fluctuations and financial stability in France. Our results show that accounting for household financial vulnerability in the distribution of loans is key to prevent large credit and house price fluctuations from reinforcing each other in the long term. Moreover, our model shows that measures constraining the indebtedness of households (regarding the maturity of loans or borrowerbased caps) helps reducing short- to medium-term financial instability dynamics.
\end{abstract}

Keywords: Semi-structural Models, House Prices, Mortgage Debt

JEL classification: E51, E47, C51

\footnotetext{
${ }^{1}$ Corresponding authors: stephane.dees@banque-france.fr (Dées) and camille.thubin@banque-france.fr (Thubin). Most of the research was conducted while G. Bove was intern at Banque de France. The authors wish to thank G. Lévy-Rueff, P. Sicisic, Y. Kalantzis, J-F. Ouvrard, M. Lemoine, P. Aldama, H. Turunen, T. Ferrière, A. Lalliard, Y. Wicky, J. André, H. Toubon and M. Falagiarda as well as participants to the 2nd Workshop on recent advances in credit analysis in the euro area (ECB -July 2019) and the Working Group of Econometric Modelling (Sept 2019). The views expressed here are those of the authors and do not necessarily reflect the views of Banque de France or the Eurosystem.

${ }^{2}$ Univ. Paris 2

${ }^{3}$ Banque de France and Univ. Bordeaux

${ }^{4}$ Banque de France
}

Working Papers reflect the opinions of the authors and do not necessarily express the views of the Banque de France. This document is available on publications.banque-france.fr/en 


\section{NON-TECHNICAL SUMMARY}

In the last two decades, residential house prices and household debt have continuously increased in France. The joint dynamics of house prices and household credit play a key role in the central banks' assessment of future developments, both from a real economy and financial stability perspectives. On the real economy side, households' real estate assets constitute a major share of their wealth and the housing debt burden appears particularly sensitive to macro-financial conditions. Any change in housing market or financing conditions could therefore have consequences on the business cycle through their impact on households' decisions. On the financial stability side, housing assets form an important part of the portfolios of banks and institutional investors and are used as collateral by households or borrowing firms. Hence, any disturbance that affects the housing market could increase the risk of a deflationary spiral between house prices and the amounts of credit granted.

The aim of this paper is to develop a model of house prices and household credit dynamics and assess how it interacts with other macro-financial variables by introducing it into the Banque de France semi-structural model (FR-BDF), which is used mainly for the macroeconomic projection exercises. Our approach focuses on an indicator of stress in the residential housing and mortgage market, which takes into account in particular the purchasing power of households and the credit financing conditions (interest rates, credit maturity). This indicator is a Debt Service Ratio (DSR) which proves particularly relevant to account for the riskiness of the borrowers in the loan origination. The value added of our approach is two-fold. First, we adopt a modelling of household loans that takes care of distinguishing new loans from repayments of past outstanding amounts, while such a key distinction is largely ignored in previous attempts. Second, by including financial stability considerations in our modelling, we are able to account for the role of macroprudential policy in stabilising risky debt dynamics and simulate the macroeconomic impact of various prudential measures related to household indebtedness.

Our econometric evidence clearly shows the prominent role of interest rates in the mortgage market dynamics, in particular following the Global Financial Crisis. The decline in bank lending rates, which have sharply declined from a peak of more than 5 percent in 2008 to a historical low of 1.2 percent in 2019, is shown to be the main explanatory factor of the continuous increase in both the DSR and house prices. While the increase in house prices in turn support mortgage debt dynamics, loan origination is however limited by debt sustainability considerations.

Our model simulations also show that accounting for household financial vulnerability in credit supply prevents the economy from going to unsustainable paths in the long term, as the distribution of loans is limited by too high a DSR. However, large credit and asset price fluctuations may reinforce each other over short- to medium-term horizons, creating potential financial accelerator effects that are detrimental to financial stability. In this context, we show that macroprudential policy measures targeting households (e.g. limiting the DSTI ratio or reducing the length of loan maturity) seem to contribute in stabilising house price and debt dynamics. 
New mortgage loans and dynamic contributions of its determinants

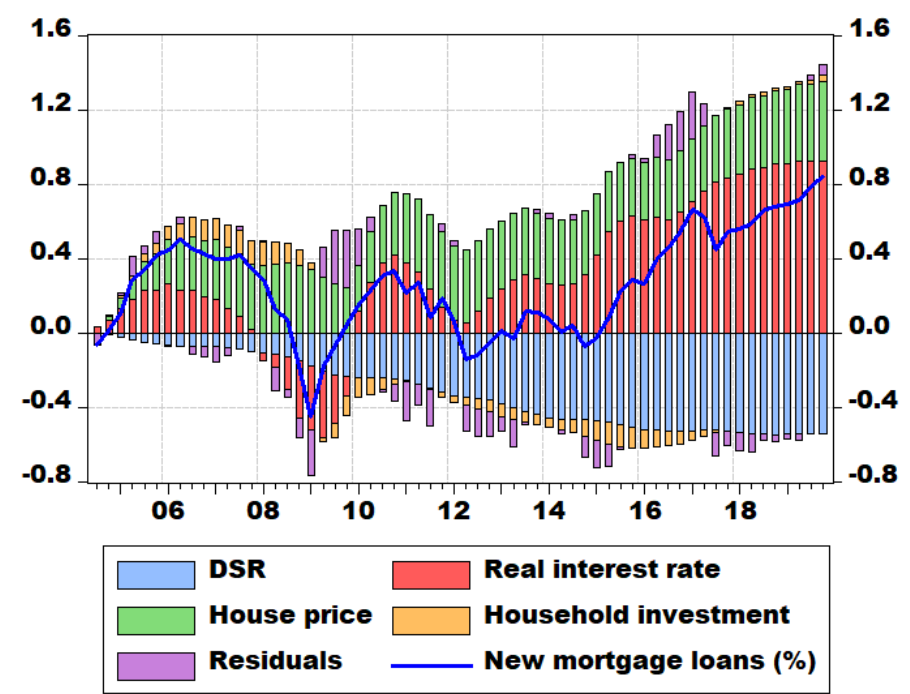

Note: New mortgage loans correspond to their cumulated \% changes over the period 2005-2019.

\section{Prix des logements, dynamique de la dette immobilière et fluctuations économiques en France : une approche semi-structurelle}

\section{RÉSUMÉ}

Nous développons un modèle de prix des logements et d'endettement des ménages et l'intégrons dans le modèle macroéconomique semi-structurel de la Banque de France afin d'analyser les implications de la dynamique de la dette immobilière sur les fluctuations économiques et la stabilité financière en France. Nos résultats montrent que la prise en compte de la vulnérabilité financière des ménages dans la distribution des prêts est essentielle pour éviter que les fortes variations du crédit et des prix de l'immobilier ne se renforcent mutuellement à long terme. De plus, notre modèle montre que les mesures de limitation de l'endettement des ménages (concernant la durée des prêts ou les plafonds d'endettement) contribuent à réduire la dynamique d'instabilité financière à court et moyen terme.

Mots-clés : modèles semi-structurels, dette immobilière, prix des logements

Les Documents de travail reflètent les idées personnelles de leurs auteurs et n'expriment pas nécessairement la position de la Banque de France. Ils sont disponibles sur publications.banque-france.fr 


\section{Introduction}

In the last two decades, residential house prices and household debt have continuously increased in France. Despite two periods of decline (in 2008-09 and in 2011-15), house prices have followed a persistent upward trend since the mid-1990: Alongside the rise in prices, the supply of housing credit has also risen since the 1990s and household debt has increased from around $50 \%$ in 1990 to almost $100 \%$ of household income in 2019. After a pause in 2013-14, the rise in housing credit has expanded again sharply since 2015. As a result, the French macroprudential authorities are paying close attention to housing debt dynamics and stand ready to take action to mitigate the associated financial stability risks (Haut Conseil de Stabilité Financière (2019)).

The joint dynamics of house prices and household credit play a key role in the central banks' assessment of future developments, both from a real economy and financial stability perspectives.

On the real economy side, households' real estate assets constitute a major share of their wealth. For tenants or first-time home owners, a change in property prices can trigger an increase in rents or a higher financial burden associated with the repayment of their mortgage, thus having a sizeable effect on living standards. From this perspective, the dynamics of property prices and credit are inextricably linked. As the housing debt burden as a proportion of French households' income (or debt service ratio - DSR thereafter) has risen sharply in recent years, any marked increase in interest rates could have a considerable impact on their future investment plans and could interrupt the upward momentum in property prices observed in recent years. Moreover, although the relative importance of wealth effects in France is subject to debate in the literature (for more details see Chauvin and Muellbauer (2018)), it may nevertheless be important to analyse to what extent housing valuation effects may have an impact on household consumption and savings. At the aggregate level, the dynamics of property prices and credit are also relevant to assess the possible synchronicity between business and financial cycles (asset prices, credit and housing investment), the main issue being whether the housing cycle is merely a reflection of the business cycle or whether it affects the business cycle directly (see Kydland et al. (2012)).

From a financial stability perspective, understanding the mechanisms at work in the joint dynamics of house prices and credit also seems crucial. The price of real estate, like

\footnotetext{
${ }^{1}$ Although one should distinguish rigorously between two periods, the 1998-2008 period, when real estate prices rose sharply, and the 2008-2019 period, when average growth rates were more moderate.
} 
any asset price, is an indicator of the degree of optimism of "animal spirits" and carries the threat of a sudden turnaround in the economic cycle, as seen during the subprime crisis in the United States. Housing assets form an important part of the portfolios of banks and institutional investors and are used as collateral by households or borrowing firms. Hence, any disturbance that affects the housing market could increase the risk of a deflationary spiral between house prices and the amounts of credit granted ${ }^{2}$.

To account for the macrofinancial impacts of house price and household debt dynamics, central banks need to adapt their workshorse modelling tools. Indeed, the global financial crisis has revealed important deficiencies in the standard macroeconomic models in their abillity to capture financial instabilities (ECB (2010)). These models have been mainly criticized for omitting key financial mechanisms and shocks stemming from the financial sector (Lindé et al. (2016)). While significant progress has been made in the DSGE modelling litterature (see e.g. Gertler and Karadi (2011) or Gertler and Kiyotaki (2015)), macro-financial linkages remain largely absent in semi-structural models used in particular for macroeconomic projections (see the DELFI model in Berben et al. (2018) and the ECB-base model in Angelini et al. (2019) as first attempts).

Once the importance of the house price/household credit block for macroeconomic modelling is recognised, the question arises as to how it should be modelled. From a theoretical perspective, household demand for credit can be derived from life-cycle models (Modigliani (1986); Friedman (1957)) where representative agents maximize their utility under an intertemporal budget constraint. Under the assumption of perfect financial markets, the agents can borrow the amount necessary to smooth their consumption or buy real estate whose services enter their utility function. The textbook models however face limitations to account for real-life situations, where agents are subject to credit constraints, explaining why consumption or investment depends more on current income than is predicted by the permanent income theory. Credit constraints, which may take the form of restrictions on the quantity of credit or the cost at which credit is granted, will progressively ease as the value of the real estate used as collateral increases, inducing a causality that goes from the price of real estate towards the outstanding amount of credit. However, the causality can go in the opposite direction: a credit boom creates pressures on house prices in a market where supply is relatively inelastic. Overall property prices and household credit share many common determinants, simply because the decision to buy a house financed by credit depends on the opportunity cost of that investment and

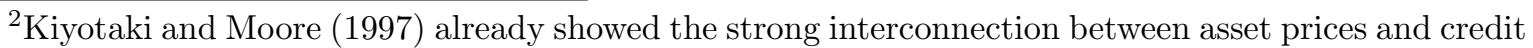
dynamics.
} 
therefore on factors such as interest rates, depreciation of the residential asset, regulations and taxation, etc.

For all these reasons, it seems theoretically relevant to model house prices and credit jointly. Each of these two variables may depend on common or specific factors, on the supply or demand sides. In the case of credit, household demand may depend on house prices, household income, the prevailing interest rate, and demographic factors (e.g. the proportion of people aged between 30 and 45 most concerned by house purchases). On the banks' side, that demand is subject to borrowing constraints, which may take various forms and depend essentially on the lenders' perceived probability of default. With regard to house prices, the assumption of an inelastic housing supply often leads modellers to favour an inverted demand equation, whose determinants (income, interest rates, household wealth, demographic or labour market factors) are partly related to those of household credit 3 .

The aim of this paper is to develop a model of house prices and household credit dynamics and assess how it interacts with other macro-financial variables by introducing it into the Banque de France semi-structural model (FR-BDF), which is used mainly for the macroeconomic projection exercises (Lemoine et al. (2019)). Our model pays attention to the impacts of mortgage debt dynamics on the real economy, distinguishing new loans from repayments of past outstanding amounts, and on the risk related to financial stability through the explicit introduction of a vulnerability indicator of households' financial conditions. Analysing the implications of house price and credit dynamics in France on economic fluctuations and financial stability is particularly interesting owing to special characteristics of the French situation with respect to the other large euro area economies. Figure 1 shows a fairly high level of house prices in France relative to its European neighbours, which one would be tempted to compare with the steady rise in French household debt over the last twenty years. As Lalliard (2017) or Dujardin et al. (2015) show, however, the house price series should be viewed with caution if one wishes to measure the degree of overvaluation of house prices. It is instead better to focus on indicators of stress in the residential housing and mortgage market, which take into account in particular the purchasing power of households and the credit financing conditions (interest rates, credit maturity). The DSR - our financial vulnerability indicator is precisely one of these stress indicators aimed at measuring the degree of overheating

\footnotetext{
${ }^{3}$ See e.g. Waldron and Zampolli (2010) where the long-term real interest rate is particularly important to explain both the build-up of debt and the rise in house prices in the United Kingdom between 1987 and 2006.
} 
on the housing market.

Figure 1: Household indebtedness and house prices in the main Euro area countries
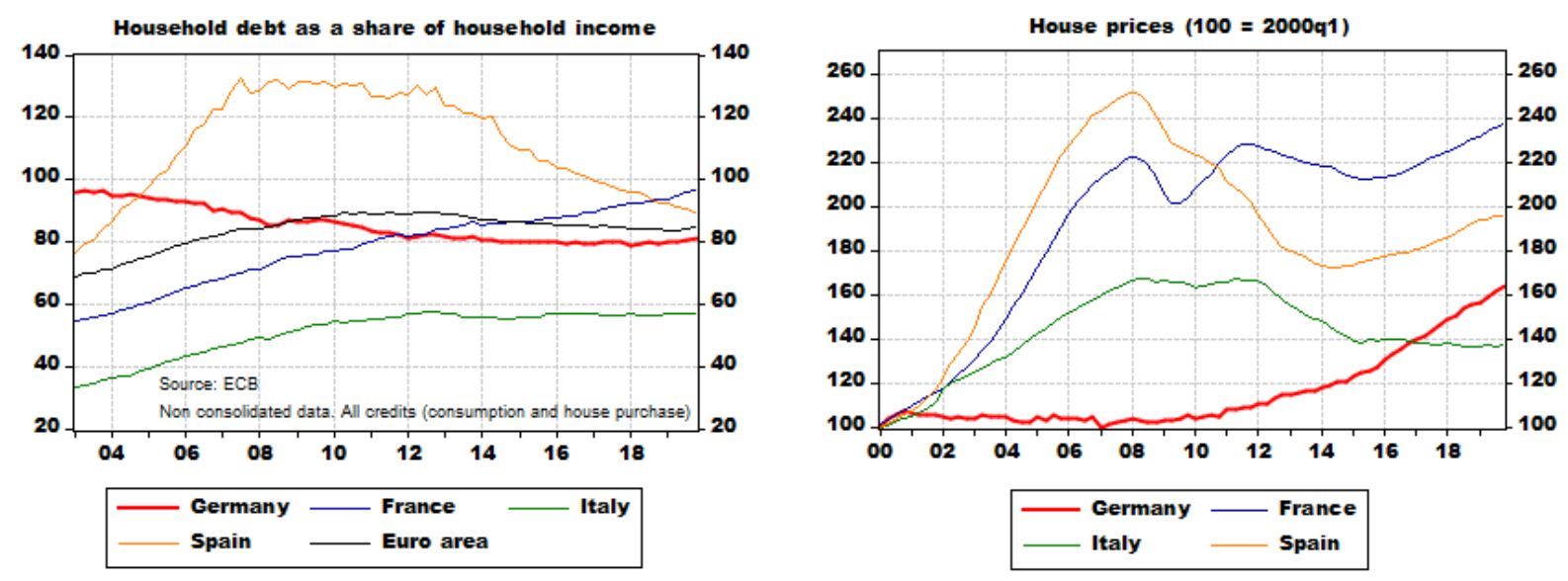

Against the background of dynamic mortgage lending in France, it is useful to understand its determinants to capture the underlying macroeconomic and financial risks. As indicated by Banque de France in its last Assessment of Risks to the French Financial System published before the Covid crisis $4^{4}$ the growth in outstanding housing loans has been driven by a record high level of transactions on the real estate market in 2019 (see Figure 2) and by the rising share of rental investment in new housing loan production. The rise in household debt and household leverage has led the HCSF (Haut conseil de stabilité financière) to recommend some "best practices" applicable to household property loans (maximum debt-service-to-income ratio - or DSTI $5^{5}$ - of $33 \%$, credit period of no more than 25 years).

The above stylised facts show that household credit and house price dynamics are likely to play a major role in economic fluctuations. Hence, it appears key to account for such dynamics in the modelling developed for producing macroeconomic projections and assessing financial stability risks, particularly for the French economy. The purpose of this article is therefore to present how we model this block and to show its key implications for the analysis of macro-financial developments. It also aims at quantifying how the properties of a macroeconomic semi-structural model (FR-BDF) are modified

\footnotetext{
$\sqrt[4]{\text { Banque de France }(2019)}$

${ }^{5}$ Note that the DSR is an aggregate indicator, i.e. at the level of the country, while the DSTI is a measure of financial vulnerability at the household level and one of the main borrower-based macroprudential policy tools.
} 
Figure 2: Transactions in old housing and housing starts in France

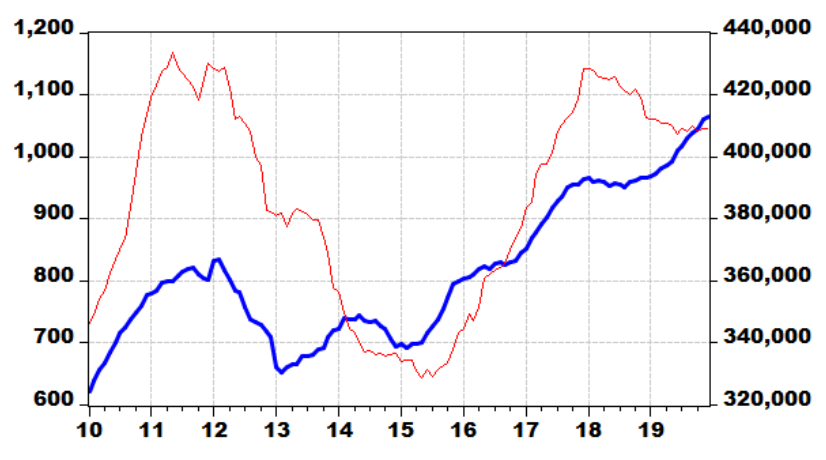

Transactions in old housing (12 months cumulated sum)

Housing starts

once housing prices and households' debt are included and how the economy reacts to shocks on household income or lending conditions (bank lending costs or supply policies). The value added of our approach is two-fold. First, we adopt a modelling of household loans that takes care of distinguishing new loans from repayments of past outstanding amounts, while such a key distinction is largely ignored in previous attempts. Second, by including financial stability considerations in our modelling, we are able to account for the role of macroprudential policy in stabilising risky debt dynamics and simulate the macroeconomic impact of various prudential measures related to household indebtedness.

Overall, our results show that accounting for household financial vulnerability in credit supply prevents the economy from going to unsustainable paths in the long term, as the distribution of loans is limited by too high a debt service ratio. However, large credit and asset price fluctuations may reinforce each other over short- to medium-term horizons, creating potential financial accelerator effects that are detrimental to financial stability. In this context, we show that macroprudential policy measures targeting households (e.g. limiting the DSTI ratio or reducing the length of loan maturity) seem to contribute in stabilising house price and debt dynamics.

The paper is organised as follows. Section 2 presents first the credit equations of our model, emphasising the importance of disentangling the modelling of new loans to households from the repayments of these loans. Section 3 presents then the modelling of house prices in greater detail. Section 4 reports in-sample and out-of-sample forecasting performance of the household credit/house price block. Section 5 shows how we plug this block into the broad macroeconomic model developed by Banque de France (FR-BDF). 
Section 6 presents our empirical experiments derived from the "augmented" model, in particular how it reacts to shocks and policies that particularly affect credit and housing markets. Section 7 concludes.

\section{Modelling households' mortgage debt dynamics}

In this section we focus on the modelling of mortgage repayments, new loans for housing and consumer loans. This set of equations will be completed thereafter by a house price equation, as described in the next section. As house price interacts strongly with new loans for house purchase, combining these equations will form the household debt model that will finally be included into the broad macroeconomic model. Our approach remains semi-structural in the sense that it relies on a right balance between a solid theoretical background and a good empirical fit.

\subsection{Accounting framework and overview of the model}

Our modelling of households' mortgage debt dynamics relies first on a careful consideration of loan data accounting by statisticians. The accounting framework of our model is based on four main interrelated variables: outstanding amounts of loans (stock), net lending flows, new loans (or loan origination) and loan repayments. This accounting framework relating these variables are described by the following equations:

$$
\begin{gathered}
D_{t}=D_{t-1}+F_{t}+\epsilon_{t} \\
F_{t}=C_{t}-R_{t}
\end{gathered}
$$

Eq. (2.1) shows how the stock of debt (outstanding amounts of loans), $D_{t}$, accumulates with net lending flows, $F_{t}$. A residual term, $\epsilon_{t}$ corresponds to adjustments related to write offs/write downs, reclassifications and sales/transfers of loans. Eq. (2.2) decomposes net lending flows into new loans, $C_{t}$, and loan repayments $R_{t}$. While these two terms follow a very different logic, the vast majority of existing econometric approaches consider credit flows as a single block. However, they should be distinguished in the modelling as they do not relate to the same determinants. On the one hand, new loans are responsive to macroeconomic conditions (household income, consumer confidence, unemployment rate, etc.), regulatory conditions (interest-free loans, taxation) and banking conditions (lending conditions, including interest rate, amount granted, maturity, etc.), and can 
be modelled econometrically. On the other hand, repayments are based more on an accounting logic: they are the result of past flows of new loans and therefore depend on the conditions under which these past flows were granted (maturity, level of interest rate, fixed or variable rate)

In addition, the data on new loans and repayments requires purging the series of credit renegotiations, as the latter do not strictly correspond to new loans, but apply new credit conditions (generally concerning the interest rate) to the remaining balance of an existing loan. The renegotiation nevertheless results in the registration of a new loan while the remaining repayment of the "old" loan is cancelled out, so that renegotiations have no impact on overall credit flows.

Figure 3 gives an overview of our household debt model. It shows in particular the breakdown of credit flows into new loans (which depend on current macro-financial conditions) and repayments (which depend on past credit and rely on accounting principles). Credit series are broken down into loans for house purchase and other credit.

Figure 3: Overview of the model

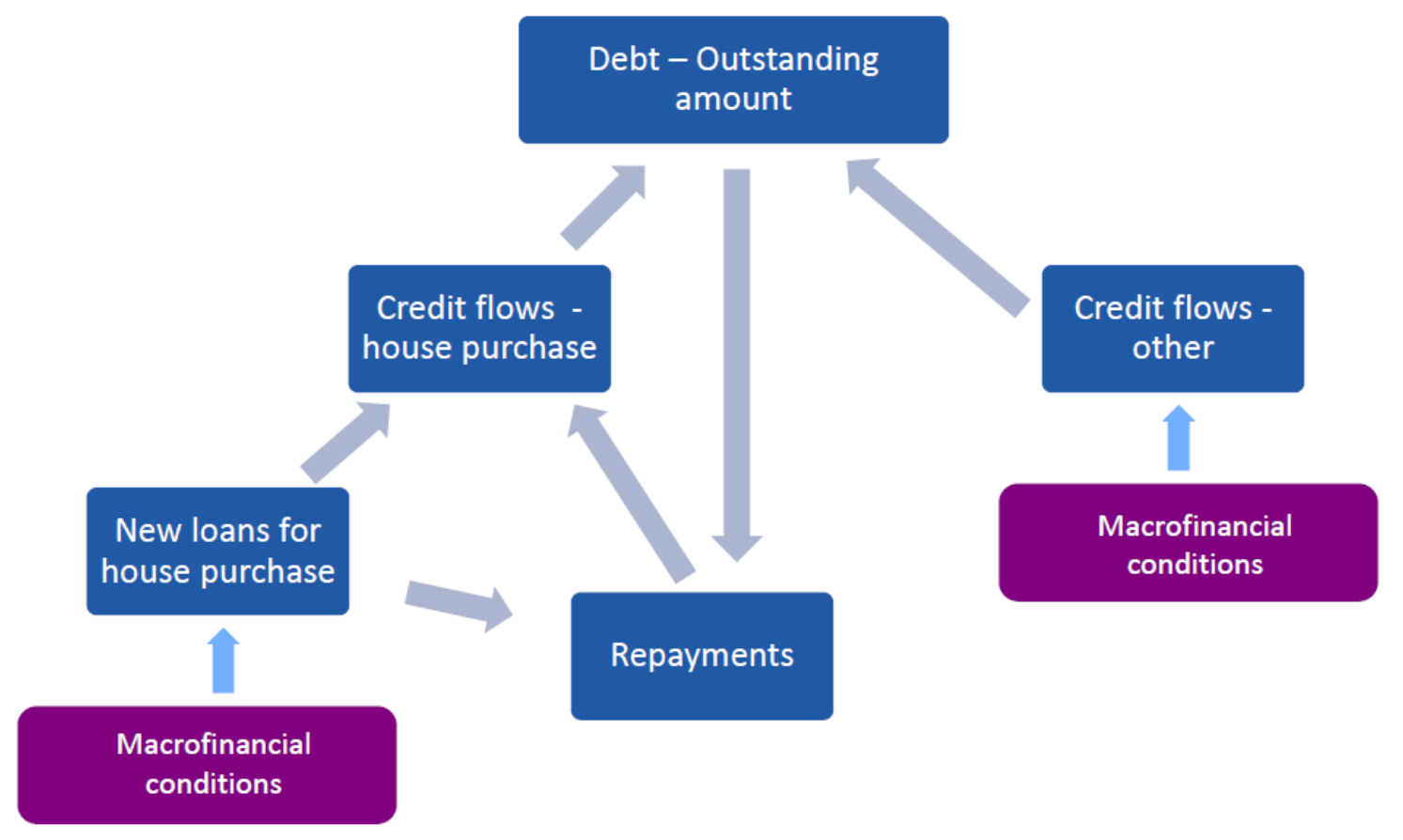

Data sources are described in Appendix B. As credit flows and new loans data are taken from different data sources, the series of repayments - deducted by difference

\footnotetext{
${ }^{6}$ Repayments may also depend on other factors, such as macroeconomic conditions (early repayments) or policy (moratoria, tax changes,..), though this does not call into question their "accounting" nature.
} 
between credit flows and new loans - is by nature statistically fragile. This will affect the selection of variables in the new mortgage loans equation, see section 2.3 below.

\subsection{Modelling mortgage debt repayments}

We consider two approaches to model mortgage debt repayments. The first approach is based on a very simple accounting method ("Method 1" in Figure 5 below), explained in detail in Adalid and Falagiarda (2018), which assumes that a loan is repaid at a fixed rate over a certain period of time with a constant monthly payment. These assumptions seem quite plausible in the case of France, where almost all credit production is at a fixed rate and with French households preferring a fairly smooth monthly payment schedule.

The detailed methodology for "Method 1" is explained in Appendix A. The repayment at date $t$ of all the loans granted in the past and still being repaid can be written:

$$
R_{t}=\sum_{v \in \omega_{t}} R_{v t}, \quad \omega_{t}=\left\{v, 0 \leq t-v \leq M_{v}\right\}
$$

where $M_{v}$ is the average maturity of loans granted a date $v$.

The main difficulty in calculating $R_{t}$ is the availability of data. At each date $t$, the amount, interest rate and maturity of all loans not fully repaid must be available. Therefore, in order to calculate the repayments corresponding to the oldest loan vintages, data for maturities and rates must be available far back in time.

In addition to the data limitation issue, this approach to calculating repayments is also difficult to insert into a semi-structural model (which is our main purpose), since it uses an algorithm involving all loan vintages and not a reduced form that could be added to the model equations.

Kydland et al. (2012) provides us with an alternative method for calculating repayments in a reduced form ("Method 2" in Figure 5). The very simple idea is to provide at each date an approximation of the effective amortization rate on the observed stock of loans. The following system of equations allows us to obtain, recursively, the outstanding debt $D_{t}$, the effective amortization rate $\delta_{t}$ and the effective interest rate $i_{t}^{*}$ at each date $t$ :

$$
\left\{\begin{array}{l}
D_{t}=\left(1-\delta_{t}\right) D_{t-1}+C_{t} \\
\delta_{t}=\left(1-v_{t}\right) \delta_{t-1}^{\alpha}+v_{t} \kappa \\
i_{t}^{*}=\left(1-v_{t}\right) i_{t-1}^{*}+v_{t} i_{t}
\end{array}\right.
$$

$C_{t}$ and $i_{t}$ are respectively the new loans granted at date $t$ and their current interest 
rate. $v_{t}=C_{t} / D_{t-1}$ is the share of new loans in the outstanding amount. $\kappa$ is a parameter that corresponds to the initial amortization rate of a loan and depends on the interest rate and maturity of the loan. Kydland et al. (2012) calibrate $\kappa$ according to the average parameters they observe at the time on US mortgage loans. The results we find are better if we consider that $\kappa$ varies over time. The second equation in 2.4 then becomes $\delta_{t}=\left(1-v_{t}\right) \delta_{t-1}^{\alpha}+v_{t} \kappa_{t}$ with

$$
\kappa_{t}=\frac{i_{t}\left(1+i_{t}\right)^{-M_{t}}}{1-\left(1+i_{t}\right)^{-M_{t}}}
$$

Figure 18 in Appendix $\mathrm{A}$ shows that the initial amortisation rate for a typical loan is fairly low since the interest charge represents a major part of the monthly instalment at the beginning of the credit repayment schedule and the amount to be repaid is large (denominator effect). In the 2003-2018 sample we find that $\kappa$ is worth $0.33 \%$ on average. It remains to calibrate the parameter $\alpha$ in the second equation, which corresponds to the "curvature" of the amortization rate, i.e. very flat for a long period and then suddenly rising to $100 \%$ at maturity, thus recalling the shape of a power law (see Figure 18 in appendix A). Here again, Kydland et al. (2012) calibrate $\alpha$ according to constant parameters that do not correspond to the conditions for granting loans in our study sample. We calibrate this parameter so that the historical series of repayments we obtain with this reduced-form approach fits as closely as possible the series obtained from the accounting approach (Method 1) described above. At the average credit conditions over the period 2003-2018, $\alpha=0.9936$ (compared to 0.9946 for the value of $\alpha$ used in Kydland et al. (2012)) is obtained.

Finally, we initialize the amount of repayments excluding renegotiation and the amortization rate with the values observed in Q1 2003, then we calculate the series for $\delta_{t}$ and $i_{t}^{*}$ with the system of equations 2.4. The value of the repayments, equal to $\tilde{R}_{t}=\delta_{t} D_{t-1}$, is deducted at each date $t$. Figure 4 (left panel) shows the amortization rate $\delta_{t}$ and its negative relationship to loan maturity that appears in particular at the beginning of the observation sample. Though not playing any role in the dynamics of repayments, the effective interest rate $i_{t}^{*}$ (Figure 4, right panel) is useful for calculating certain ratios, such as the DSR, which provides a better measure of debt sustainability than the simple ratio of the current interest burden to household gross disposable income. As we will see below, the DSR plays a central role in our overall model of household indebtedness and house prices.

Figure 5 shows the repayments schedule we obtain with the accounting method (accounting for each successive generation of granted loans) on one hand and with the 
Figure 4: Amortization and effective interest rate
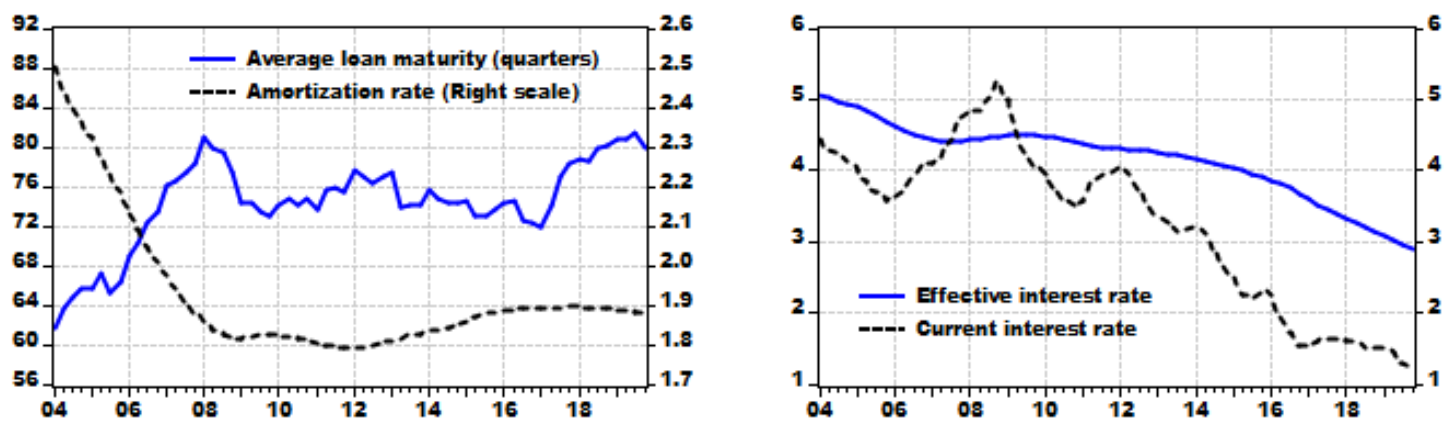

reduced form approach on the other hand. Both methods provide a relatively satisfactory way of determining the long-term trend in repayments and allowing to account for the lasting effects of past debt dynamics, thus keeping a "memory" of household debt behaviour throughout the maturity of their loans.

Figure 5: Observed vs. simulated repayments (in billions of euros)

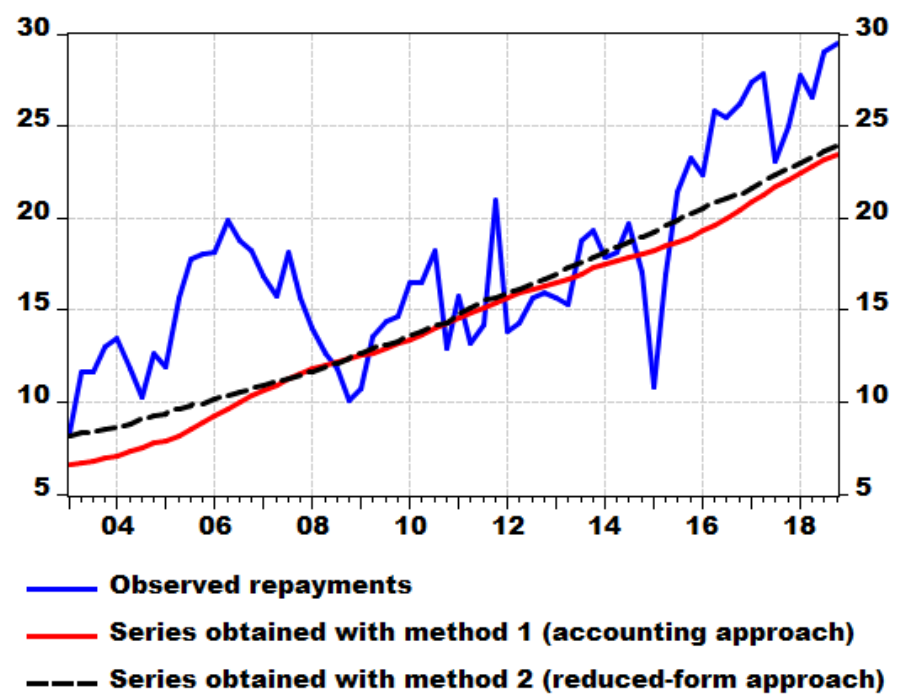

Turning to the data, it seems that short-term dynamics of repayments are in fact quite volatile, inducing significant fluctuations around the trend computed with the methods described above (see Figure 5). When trying to model the short-term dynamics according to an error correction equation, none of the short-term determinants we have tested appear with a significant coefficient. In a sense, this supports our approach of focusing 
on the trend in repayments. In the full model of household debt dynamics presented in the subsequent sections, repayments will be modelled with the simple following equation:

$$
\Delta r_{t}=\alpha^{R}+\beta^{R}\left(r_{t-1}-\tilde{r}_{t-1}\right)+\epsilon_{t}^{R}
$$

Where $r$ is the observed repayment and $\tilde{r}$ is the long-term trend determined from the method of Kydland et al. (2012) (all variables in logs). The estimated $\beta^{R}$ coefficient is quite high (-0.24) and significant at the $1 \%$ threshold.

\subsection{Modelling new mortgage loans}

After the modelling of repayments, our household debt model requires linking the production of new mortgage loans to macro-financial conditions. Theoretically, mortgage new loans respond to demand factors on the household side (income, unemployment, etc.), to supply factors on the banking side (cost of borrowing, quantitative restrictions, etc.), to the real estate market conditions (property prices, housing supply, etc.) and to macroeconomic conditions (growth, inflation, interest rates, etc.).

As a central element in the modelling of household debt dynamics, the estimation of a new housing loan equation must meet two requirements: (1) have reasonable coefficients (sign, magnitude) and good forecasting performance; (2) have good simulation properties once it is integrated into a macroeconomic model. The first requirement will be examined here while we leave the examination of the second requirement for Section 6 .

The selected specification is based on an error-correction model similar to the other FR-BDF model equations. The selection of variables among many potential explanatory factors (interest rates, household income, unemployment rate, house prices, household investment, inflation, GDP, household debt service ratio,...) was made following a forecasting "horse race", which combined in-sample and out-of-sample performance analysis. One of the best specifications satisfying the first requirement mentioned above is the following:

$$
\begin{array}{r}
c_{t}^{H *}=\alpha_{0}^{H}+p_{t}^{H}+I_{t}^{H}+\alpha_{1}^{H} D S R_{t}+\alpha_{2}^{H}\left(i_{t}^{l}-\pi_{t}^{e}\right) \\
\Delta c_{t}^{H}=\beta^{H}\left(c_{t-1}^{H *}-c_{t-1}^{H}\right)+\gamma_{1}^{H} \Delta c_{t-1}^{H}+\gamma_{2}^{H} \Delta c_{t-2}^{H}+\gamma_{3}^{H} \Delta\left(i_{t}^{l}-\pi_{t}^{e}\right)+\gamma_{4}^{H} I^{H} d^{H}+\epsilon_{t}^{H}
\end{array}
$$

With $c_{t}^{H}$ the production of new housing loans, $p_{t}^{H}$ the house price, $I_{t}^{H}$ residential investment, $D S R_{t}$ the debt service ratio, $i_{t}^{l}-\pi_{t}^{e}$ the real interest rate and $I n d^{H}$ is an indicator variable for the Global Financial Crisis (GFC). $c_{t}^{H *}$ represents the long-term 
target of new loans corresponding to the cointegration relationship described in Equation 2.7. All variables are in log except for the real interest rate. Three elements on the explanatory variables need to be clarified. First, we constraint in the long term new mortgage loans to evolve fully in line with the amount invested in housing. This explains the unit coefficients of $p_{t}^{H}$ and $I_{t}^{H}$. Second, the real (long-term) interest rate $i_{t}^{l}-\pi_{t}^{e}$ is computed with an inflation expectation term $\pi_{t}^{\in 7}$. Third, the debt service ratio, $D S R$, is obtained with the effective amortization rate $\delta_{t}$ and the effective interest rate $i_{t}^{*}$ that we compute when modelling mortgage debt repayments (see Section $24^{8}$. It is equal to the ratio of loan amortization plus interest expense over household income:

$$
D S R_{t}=\frac{\left(\delta_{t}+i_{t}^{*}\right) D_{t-1}^{H}}{Y_{t}}
$$

The debt service ratio is a crucial variable that stabilizes the dynamics of the model and generates low-frequency movements after exogenous shocks due to the presence of a stock variable in its numerator. In addition, this indicator seems to adequately represent the degree of tension on the residential housing and mortgage market that was mentioned in the introduction and presented in Lalliard (2017). In France the DSR has been continuously increasing in the 2000s before stabilising after 2013 thanks to very low interest rates (see Figure 6).

Equation 2.7 defines the long-term target of new housing loans that depends on both supply and demand side determinants. As explained in Chen and Chivakul (2008), this can be considered as a reduced form summarizing an Heckman-like two-stage selection process: in the first stage, households decide to enter or not in the debt market depending on demand-side factors (income, probability of being unemployed, interest rate, etc.), while in the second stage, lenders decide whether and how much to lend, considering the capacity of their potential borrowers to repay as well as their own financing constraints. In that sense, house prices and residential investment could be considered as demand factors while the debt service ratio could be considered as a supply factor, since it can be used by financial intermediaries to gauge the riskiness of the borrower.

\footnotetext{
${ }^{7}$ The expected inflation rate is an output of the FR-BDF model. See Section 5.1 for further details.

${ }^{8}$ Note that instead of computing the $D S R$ with the effective amortization rate $\delta_{t}$ and the effective interest rate $i_{t}^{*}$ derived from the reduced form approach in section 2 we could have used in our new mortgage loans equation the "observed" DSR. This latter variable can be calculated as the ratio of "observed" repayments (calculated as the difference between new loans and credit flows, themselves derived from two different databases) plus the interest burden on household disposable income. But as mentioned in section 2.1, the series of "observed" repayments is statistically fragile and leads also to a very fragile DSR series (not shown here), whose explanatory power in an econometric equation has been tested but found not to be significant.
} 
Figure 6: Debt service ratio (in \% of gross disposable income)

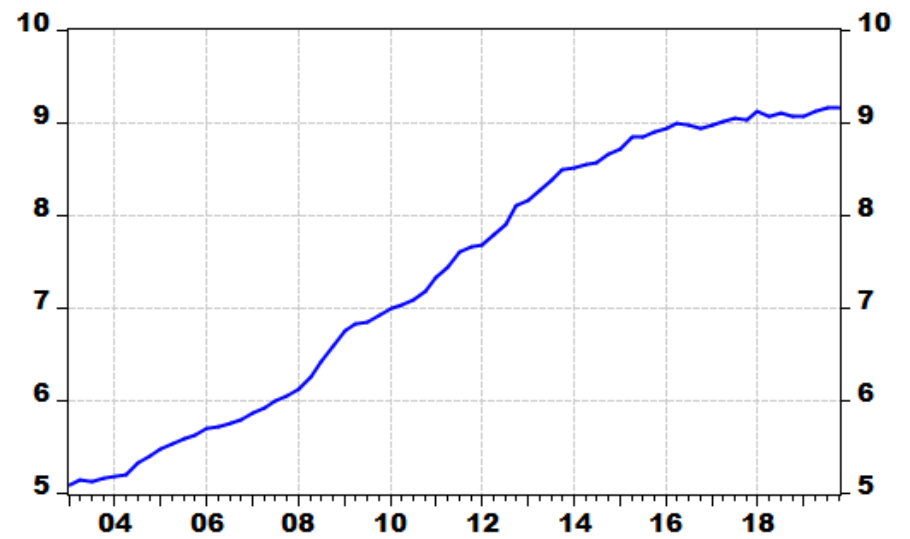

A last point that is useful to mention on equation 2.7 is the presence of the real interest rate variable $i_{t}^{l}-\pi_{t}^{e}$ while the residential investment variable is already supposed to capture the negative effect of a tightening of lending rates on loan demand from households. However, households use their loan both to invest in new housing and to finance transactions in old housing. The boom in transactions observed in 2019 while residential investment remained subdued (see Figure 2) certainly explains part of the recent dynamics of new housing loans. We considered the possibility of including transactions on existing dwellings as a determinant of new loans, but the difficulty of predicting these transactions in a macroeconomic model led to exclude this approach 9 . However, we interpret the additional effect of real interest rates - beyond its impact on residential investment in equation 2.7 - to some extent as an indirect impact through transactions on household loan demand.

Table 1 shows the estimation results for the new mortgage loans equation. As mentioned above, long-term coefficients on house prices and residential investment are constrained to on $\AA^{10}$. All other coefficients are highly significant with expected signs.

Figure 7 (left panel) shows that the dynamic simulation captures relatively well the movements of new mortgage loans except at the end of the simulation period when new

\footnotetext{
${ }^{9}$ We tested alternative specifications including transactions: the results are better in the recent period but are broadly similar over the simulation period (results of these simulations are available from the authors upon request).

${ }^{10}$ This constraint is also necessary to ensure the long-term convergence of credit towards a balanced growth path as part of the integration of these equations in the FR-BDF semi-structural model (see section 5 below). When the constraint is relaxed, the coefficients obtained are not significantly different from one.
} 
Table 1: Estimation results for the new mortgage loans equation

\begin{tabular}{lcc}
\hline Variable & Coefficient & Value \\
\hline Error correction term & $\beta^{H}$ & $0.55^{* * *}$ \\
Long-term variables & & \\
$\quad D S R_{t}$ & $\alpha_{1}^{H}$ & $-0.15^{* * *}$ \\
$\quad i_{t}^{l}-\pi_{t}^{e}$ & $\alpha_{2}^{H}$ & $-0.34^{* * *}$ \\
Short-term variables & & \\
$\Delta c_{t-1}^{H}$ & $\gamma_{1}^{H}$ & $0.35^{* * *}$ \\
$\Delta c_{t-2}^{H}$ & $\gamma_{2}^{H}$ & $0.29^{* *}$ \\
$i_{t}^{l}-\pi_{t}^{e}$ & $\gamma_{3}^{H}$ & $-0.20^{* *}$ \\
Ind $^{H}$ & $\gamma_{4}^{H}$ & $-0.28^{* * *}$ \\
Adjusted $R^{2}$ & & 0.47 \\
\hline${ }^{* * *},{ }^{* *}$ and ${ }^{*}$ denote the $1 \%, 5 \%$ and $10 \%$ significance levels.
\end{tabular}

mortgage loans follow a very bumpy profile that is difficult to predict. The right panel shows the dynamic contributions of explanatory variables to the cumulated change in the long-term target of new mortgage loans (equation 2.7). We can clearly see the prominent role of the real interest rate in the new mortgage loans dynamics, in particular during the GFC and in the recent years. House prices contribute also positively after the recession episode. Furthermore, credit dynamism is limited by debt sustainability considerations (DSR) over the whole historical sample.

Figure 7: Simulated new mortgage loans and dynamic contributions
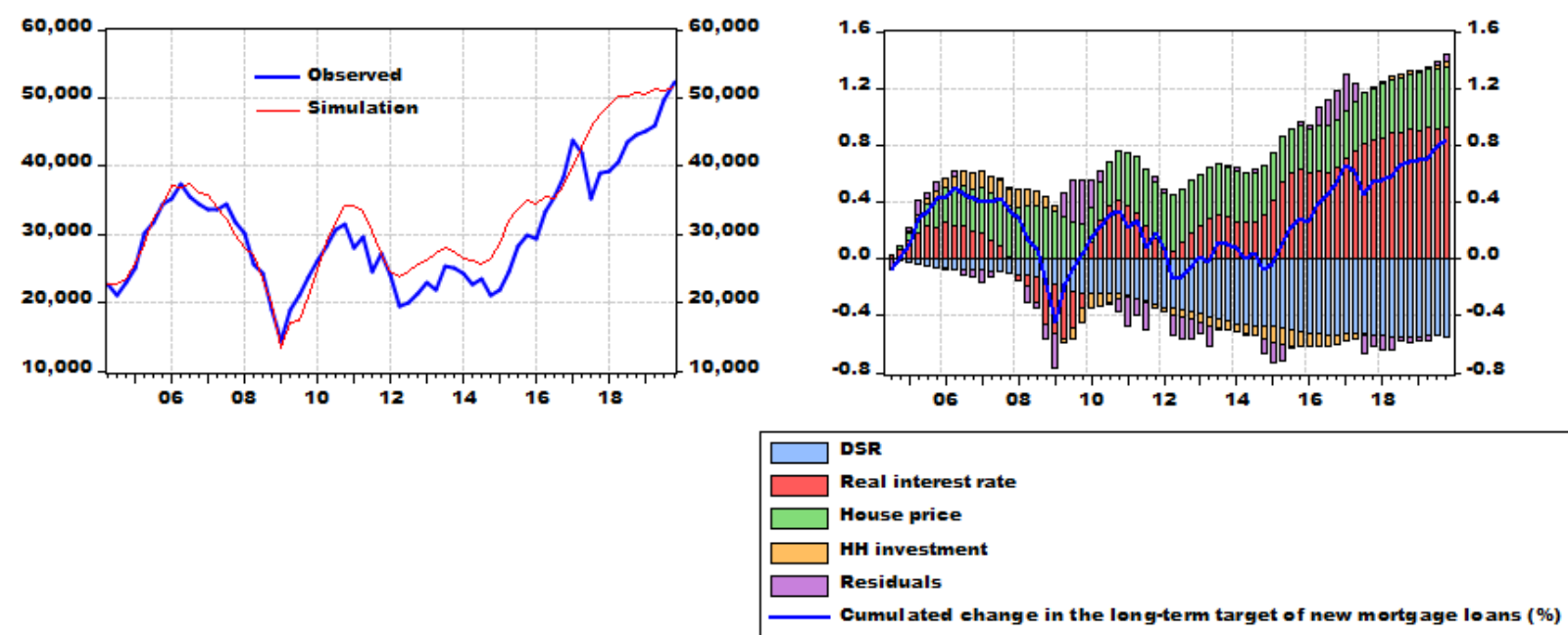


\subsection{Modelling other household loans}

Other household loans, corresponding mainly to consumer credit, are modelled as credit flows due to the absence of information on new loans. The specification of the equation is kept simple, assuming that credit flows $\left(C_{t}^{O}\right)$ as a share of nominal disposable income $\left(Y_{t}\right)$ depend on real short-term interest rates (with $i_{t}^{s}$ the nominal short-term interest rate and $\pi_{t}^{e}$ the expected inflation rate). A dummy variable is also added to account for structural changes in consumer credit (e.g. Lagarde law in 2010 that tightened conditions for consumption credit or the increasing share of car leasing in the most recent period).

$$
\frac{C_{t}^{O}}{Y_{t}}=\gamma_{0}^{O}+\gamma_{1}^{O} \Delta\left(i_{t}^{s}-\pi_{t}^{e}\right)+\gamma_{2}^{O} d u m m y+\epsilon_{t}^{O}
$$

Table 2: Estimation results for the other household loans equation

\begin{tabular}{lcc}
\hline Variable & Coefficient & Value \\
\hline$i_{t-1}^{s}-\pi_{t}^{e}$ & $\gamma_{1}^{O}$ & $-0.21^{*}$ \\
Ind ${ }^{O}$ & $\gamma_{2}^{H}$ & $-0.006^{* * *}$ \\
Adjusted $R^{2}$ & & 0.34 \\
\hline${ }^{* * *},{ }^{* *}$ and ${ }^{*}$ denote the $1 \%, 5 \%$ and $10 \%$ significance levels.
\end{tabular}

Figure 8: Observed vs. simulated other household loans

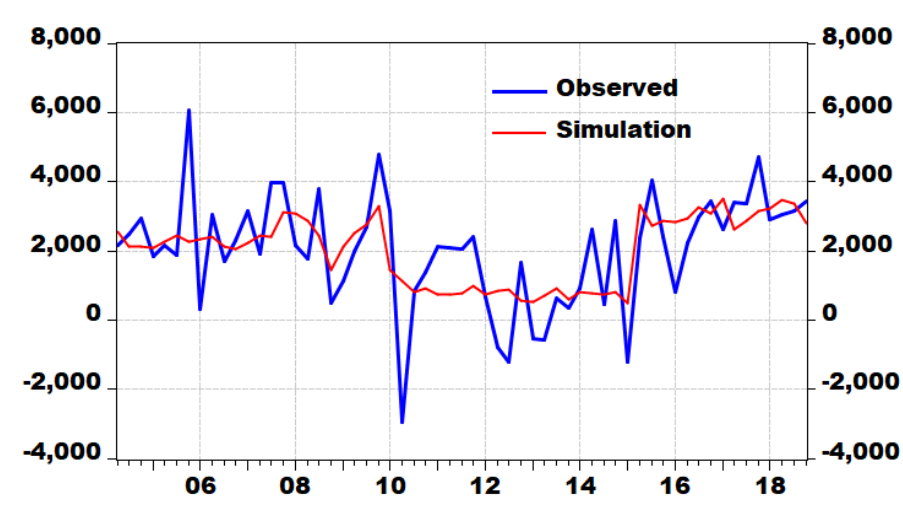

Figure 8 shows that it is difficult to capture short-term variations in this series, which is likely related to some statistical noise $£^{11}$. At the same time, this equation allows us to complete our model of household indebtedness as described in Figure 3.

\footnotetext{
${ }^{11}$ Other variables such as consumption of durables or consumer confidence could help capturing some of the short-term volatility of the series. However, we are constrained by the fact that all explanatory
} 


\section{Modelling housing market dynamics}

We turn now to the modelling of the other main building block of the household debt model, i.e. house prices. The selected specification is derived theoretically by considering a target for house prices coming from an inverted demand equation. This demand equation results from the optimization problem of the consumer who chooses between different consumption sub-components (here between consumption and investment). The representative consumer solves her maximization problem by equalizing the real user cost of housing ownership to the marginal rate of substitution between consumption goods and housing services. Based on the same approach as in the ECB-Base model Angelini et al. (2019) ) but keeping the assumption of an elasticity of substitution equal to one, this leads to the following long-term specification:

$$
p_{t}^{H *}=\alpha_{0}^{P}+Y_{t} / K_{t}^{H}+\alpha_{1}^{P}\left(i_{t}^{l}+d_{t}-\pi_{t}^{e}\right)
$$

with $p_{t}^{H *}$ is the long-term target for the real house price, $Y_{t}$ the real household income, $K_{t}^{H}$ the real housing capital, $i_{t}^{l}$ the long-term interest rate, $d$ the housing capital depreciation rate and $\pi_{t}^{e}$ the expected inflation rate. $\left(i_{t}^{l}+d_{t}-\pi_{t}^{e}\right)$ is the user cost of housing capita ${ }^{12}$.

Finally, short-term explanatory variables complete the modelling:

$$
\Delta p_{t}^{H}=\beta^{P}\left(p_{t-1}^{H *}-p_{t-1}^{H}\right)+\gamma_{1}^{P} \Delta p_{t-1}^{H}+\gamma_{2}^{P} \Delta\left(i_{t-1}^{l}+d_{t-1}-\pi_{t-1}^{e}\right)+\gamma_{3}^{P} \Delta c_{t-1}^{H}+\epsilon_{t}^{P}
$$

Table 3 shows the estimation results for the house price equation. All coefficients are highly significant with expected signs. The magnitude of the autoregressive coefficient suggests that any shock to this variable results in very persistent dynamics.

Figure 9 (left panel) shows that the dynamic simulation captures relatively well the movements of house prices even if the magnitude of peaks and troughs is only partially explained. Turning to the dynamic contributions of the explanatory variables to the year-on-year growth rate of new house prices (right panel), we can see the importance of financial variables (credit, interest rate) that contribute the most in particular during the

variables in our equations must themselves be predictable, since our final objective is to add our household credit block as part of a more general forecasting model.

${ }^{12}$ Note that housing supply factors are also allowed here to play a role through the presence of real housing capital in the long-term specification of house prices. Therefore, this specification can capture any impact related to sticky housing supply, especially in metropolitan areas, that could explain the recent pick-up in France of house prices. 
GFC downturn and the subsequent recovery. The equation is somewhat less performant in explaining price dynamics over the more recent period.

Table 3: Estimation results for the house price equation

\begin{tabular}{lcc}
\hline Variable & Coefficient & Value \\
\hline Error correction term & $\beta^{P}$ & $0.04^{* * *}$ \\
Long-term variables & & \\
$i_{t}^{l}+d_{t}-\pi_{t}^{e}$ & $\alpha_{1}^{P}$ & $-0.04^{* *}$ \\
Short-term variables & & \\
$\Delta p_{t-1}^{H}$ & $\gamma_{1}^{P}$ & $0.73^{* * *}$ \\
$i_{t-1}^{l}+d_{t-1}-\pi_{t-1}^{e}$ & $\gamma_{2}^{P}$ & $-0.009^{* *}$ \\
$\Delta c_{t-1}^{H}$ & $\gamma_{3}^{P}$ & $0.02^{* *}$ \\
Adjusted $R^{2}$ & & 0.91 \\
\hline${ }^{* * *},{ }^{* *}$ and ${ }^{*}$ denote the $1 \%, 5 \%$ and $10 \%$ significance levels.
\end{tabular}

Figure 9: Simulated house prices and dynamic contributions
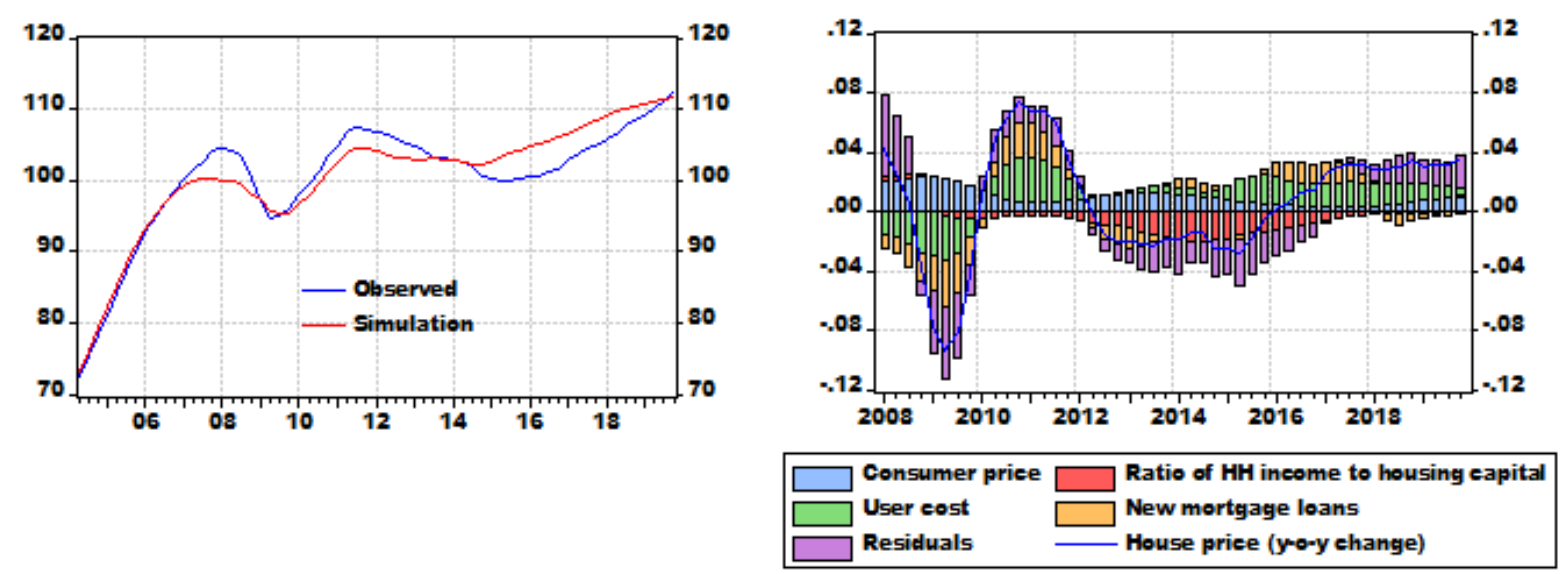


\section{In-sample and out-of-sample forecasting performance}

Our household debt model combines the different equations described so far. More precisely, Eq. 2.4 and 2.6 give us the amortization rate and the repayments dynamics. Combined with the new housing loans equation (Eq. 2.8), we obtain net lending flows for housing that increment the stock of housing debt. The total stock of debt is then obtained by adding the equation for other loans (Eq. 2.10). Finally, house prices (Eq. 3.1 and 3.2 are a major part of this system since they determine the long-term target for new house loans while being also driven by credit dynamics in the short term.

Turning now to the forecasting performance of this system of equations, Figure 10 presents the results of an in-sample dynamic simulation of the model over the period 2003-2019. Overall the model seems to capture relatively well the joint dynamics of household debt and house prices. New house loans are overestimated over the recent period. However, the boom in transactions observed in 2019 (while household's residential investment - which determines new loans in the model - remained subdued) explains why the simulation finally converges to the observed series at the very end of the historical sample. The divergence between the observed total stock of debt and the model simulation at the end of the simulation period also stems from the overestimation of consumer loans, despite the dummy variable that is supposed to capture the effect of regulations on this segment of the credit market.

Figure 10: Dynamic simulation of the model
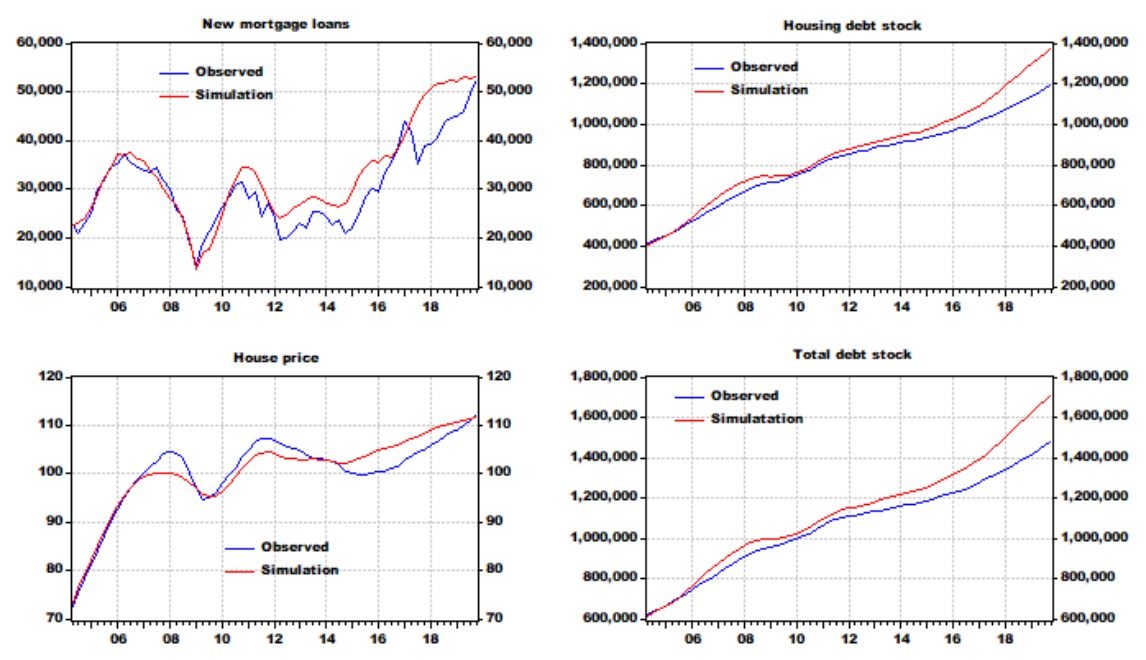

Turning to the out-of-sample forecasting performance, we conduct two distinct anal- 
yses. First, we compute the root mean square error (RMSE) for the single new house loan equation and compare it to two naive benchmarks (random walk and autoregressive models). Second, we simulate the whole model and compute the RMSE for the year-on year growth rate of the total stock of household debt, and compare it with that of the existing FR-BDF model used here as a benchmark.

Table 4 shows the RMSE for the new house loans equation compared to the naive benchmarks at different forecast horizons ${ }^{13}$ (from $h=0$ for nowcast to $h=4$ for 4 quarters ahead forecast). RMSE are computed on cumulated growth rates over $h$ periods of time. The evaluation sample is the $2013-2018$ period. The model equation beats the random walk at each forecast horizon. The RMSE for the model equation and the AR equation are quite similar for short-term forecast horizons, but the model equation seems to perform better for longer horizons.

Table 4: RMSE for the new house loans equation

\begin{tabular}{cccc}
\hline Time horizon & Model equation & AR & RW \\
\hline$h=0$ & 0.09 & 0.09 & 0.11 \\
$h=1$ & 0.14 & 0.13 & 0.20 \\
$h=2$ & 0.17 & 0.16 & 0.32 \\
$h=3$ & 0.17 & 0.18 & 0.43 \\
$h=4$ & 0.16 & 0.22 & 0.56 \\
\hline
\end{tabular}

RMSE are computed on percentage change of new house loans.

Looking now at the forecasting performance of the whole model, we choose as a benchmark the two-equations system for household credit and house prices in the FRBDF model. The dependent variable in the FR-BDF household credit equation is credit net flows. The explanatory variables are residential investment in the long term and house prices in the short term. House prices in FR-BDF are modelled with a very simple $\mathrm{AR}(2)$ equation. The RMSE are computed in pseudo-real time, i.e. we use for exogenous variables (interest rates, residential investment, household income, consumer prices) the forecasts made in each successive round of Eurosystem projection exercises. RMSE are computed on cumulated growth rates over $h$ periods of time of the total stock of household debt. Table 5 shows that the longer the forecast horizon, the higher the relative forecasting performance of our model compared to the benchmark.

Overall, it seems that the household debt model presented in this paper has some undeniable theoretical advantages (richer macroeconomic channels, decomposition of loan

\footnotetext{
${ }^{13} \mathrm{Lags}$ in the $\mathrm{AR}$ equations are chosen in order to minimize the BIC criterion.
} 
flows into new loans and repayments) that do not come at the expense of its forecasting performance relative to more basic alternatives.

Table 5: RMSE for the whole model compared to the FR-BDF two-equations system (2013 - 2018)

\begin{tabular}{ccc}
\hline Time horizon & Model equation & Benchmark \\
\hline$h=0$ & 0.24 & 0.26 \\
$h=1$ & 0.47 & 0.59 \\
$h=2$ & 0.73 & 1.03 \\
$h=3$ & 1.01 & 1.58 \\
$h=4$ & 1.08 & 2.23 \\
\hline
\end{tabular}

RMSE are computed on percentage change of total stock of debt.

\section{Including the household debt block in a macroe- conomic model}

This section presents very briefly the FR-BDF mode 14 . Thereafter, we show the different adjustments needed to integrate our new household debt modelling framework into a large-scale macroeconomic such as FR-BDF.

\subsection{The FR-BDF model}

FR-BDF is a semi-structural, large-scale model for France, which is used both for mediumrun projection exercises and for policy analysis.

Two key features of the model allow it to better take into account macro-financial linkages compared to more traditional macroeconomic tools. First, FR-BDF has a number of rich financial channels, for instance a large set of interest rates, an endogenous term structure and a breakdown of the different financing costs for firms. Second, expectations play an explicit role, both for financial and non-financial variables, as expectations are a major transmission channel of monetary policy shocks. In addition, work is under way at the Banque de France to further enhance the macro-financial channels of the model in particular along two dimensions, firms financing decisions and household debt dynamics. As mentioned earlier, household debt in the FR-BDF model is modelled with a single

\footnotetext{
${ }^{14}$ For more details see Lemoine et al. (2019) for a comprehensive view of the model and Aldama and Ouvrard (2020) for the presentation of the model elasticities.
} 
equation relating credit net flows (with all the caveats associated with this variable) to house prices and residential investment, while house prices follow a very simple $\operatorname{AR}(2)$ process.

\subsection{Decomposing net assets of households and property income}

In order to include the household debt block in FR-BDF, we need first to modify the equations of the large-scale model that link together household property income, net borrowing and the net financial position. Household property income in FR-BDF is derived by applying an apparent rate of return to household net assets, which themselves are obtained from the equality between the change in net assets and household net borrowing plus a residual term. We adjust these equations in several dimensions:

- We decompose net assets into gross assets and liabilities, since our model gives us the outstanding amount of household debt which constitutes almost all of the household liabilities.

- We add a revaluation term in the equation giving the change in net assets, thus extracting it from the residual term of the former equation. This revaluation term can be modelled quite easily with an equation determining equity prices (see appendix C to see how we model equity prices).

- Gross assets are then derived from net assets and gross liabilities.

- We substitute for the FR-BDF equation of net property income two equations giving property income received by households on one hand and property income paid by households on the other hand. Each of these equations equalizes property income to the product of an apparent rate of return applied on the underlying stock (gross assets vs. gross liabilities).

- Finally, there are two equations modelling apparent rates of return for property income both received and paid by households. These equations are shown in appendix D. Their explanatory variables are risk-free rates and the cost of equity.

\subsection{Long-term properties of model}

Before turning to simulations and policy analyses, we study the long-term properties of our household debt block integrated in the FR-BDF model. We are interested in 
particular to the long-term behaviour of key variables like the DSR and house prices once we let the equilibrium properties of the model play; i.e. how they converge towards steady-state levels. We need first to note that the last decades have been rather peculiar in terms of variable dynamics. Figure 11 shows that the bank lending rates in nominal terms have sharply declined from a peak of more than 5 percent in 2008 to a historical low of 1.2 percent in 2019. As shown by our econometric analysis, this decline has been the main explanatory factor of the continuous increase in both the DSR and house prices. As the long-term equilibrium value of interest rates is beyond the scope of the current paper, we study three different scenarios of interest rate projections until 2050. The first (blue line) assumes that the bank lending rates remain fixed at their current level. The second scenario (red line) assumes a gradual return to the 2003-2019 average value (i.e. 2.4 percent). The third one (green line) assumes a gradual increase up to the maximum value seen over this sample (i.e. 5.3 percent).

Figure 11 reports the convergence paths of the DSR and house prices according to these three different scenarios. If interest rates were to remain at their last historical value, the DSR would increase further until 2030 before gradually converging towards an equilibrium close to its current value. This shows that in our model, as too high a DSR constraints the production of loans, the indebtedness of households would be bounded in the long term. The second scenario (return of rates to historical sample average) points to a gradual adjustment of the DSR from its current level to lower levels close to those reached at the end of the 2000s. The third scenario, which envisages a stronger increase in interest rates, would lead to a further reduction in the DSR towards early 2000s levels.

Figure 11: Sensitivity of steady state to bank lending rates
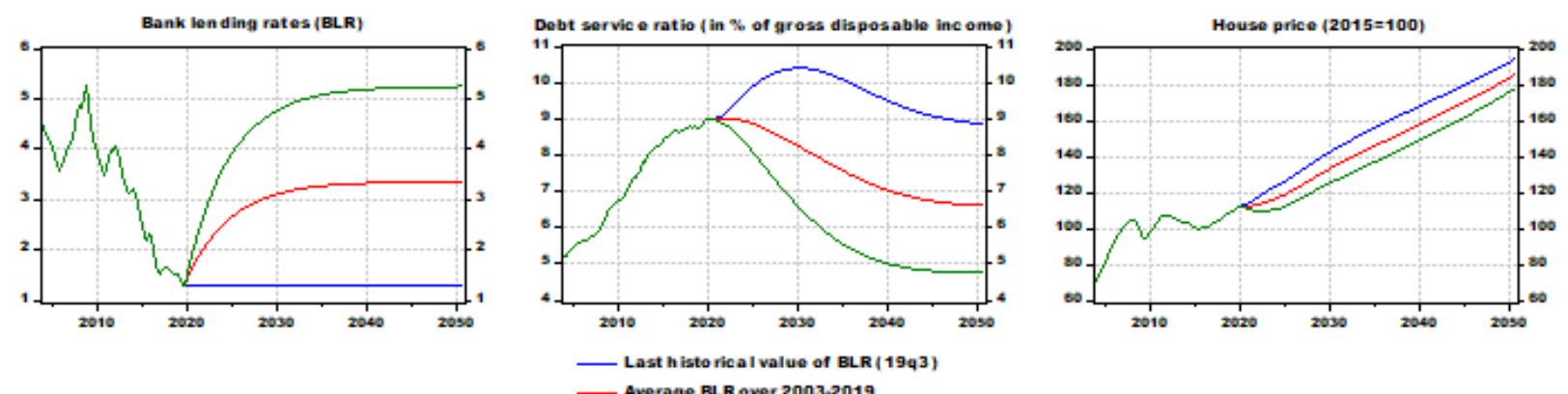

- Average BLR over 2003-2019

_- Maximal value of BLR o ver 2003-2019

House prices follow in each scenario an upward trend in line with its long-term growth 
rate value. However, the scenarios including increases in interest rates lead to a 5-year period of stable or slightly declining house prices. Only the first scenario, with interest rates constant at their current value, envisages a continuous increase in house prices at the pace observed in the last years.

\section{$6 \quad$ Simulations and policy analyses}

With our household debt block integrated into the FR-BDF model, we can now move to the study of several model experiments, through impulse response analyses. First, we analyse to what extent adding household debt dynamics into a macroeconomic model change its properties by comparing the impulse response functions of standard shocks (long term sovereign rate and income shocks). In a second step, we turn to the analysis of shocks that are more specific to the issue of household debt dynamics (lending rate and house price shocks). In the final subsection, we study the model responses to macroprudential policy shocks (decrease in loan maturity and tighter limits to the DSR as our borrower-based indicator), aimed at stabilizing household debt dynamics and inflationary pressures in real estate markets.

\subsection{IRFs of long-term rate and income shocks in FR-BDF with or without household debt dynamics}

In this subsection we compare the model responses to standard shocks (shocks on the risk premium on long-term interest rates and on income) between the current version of the FR-BDF model (without household debt dynamics) and its "augmented" version that incorporates the household debt block. The responses are computed on a relatively short term horizon (4 years), which corresponds to the so-called BMEs (basic model elasticities) horizon. This time horizon is the one that is used to compare model responses to exogenous shocks across the different projection models of Eurosystem national central banks.

Figure 12 shows the IRF of a $100 \mathrm{bp}$ risk premium shock on long term interest rates (10 years sovereign rate) that is kept constant for 4 years. The aggregate response of GDP in the two simulations is broadly similar, but the responses of demand components (household investment and consumption) are quite different. Household investment reacts much stronger in the augmented version of FR-BDF, which comes from the drop in house prices when long-term rates are pushed upwards. This channel is missing in the current 
version of FR-BDF where house prices simply follow an autoregressive process of order 2. On the other hand, household consumption decreases slightly less in the augmented FR-BDF simulation, since the risk premium shock has a positive impact on household property income, which partially compensates for the recessive impact of higher rates on household labour and operating income.

Figure 12: IRF of a 100bp sovereign rate shock
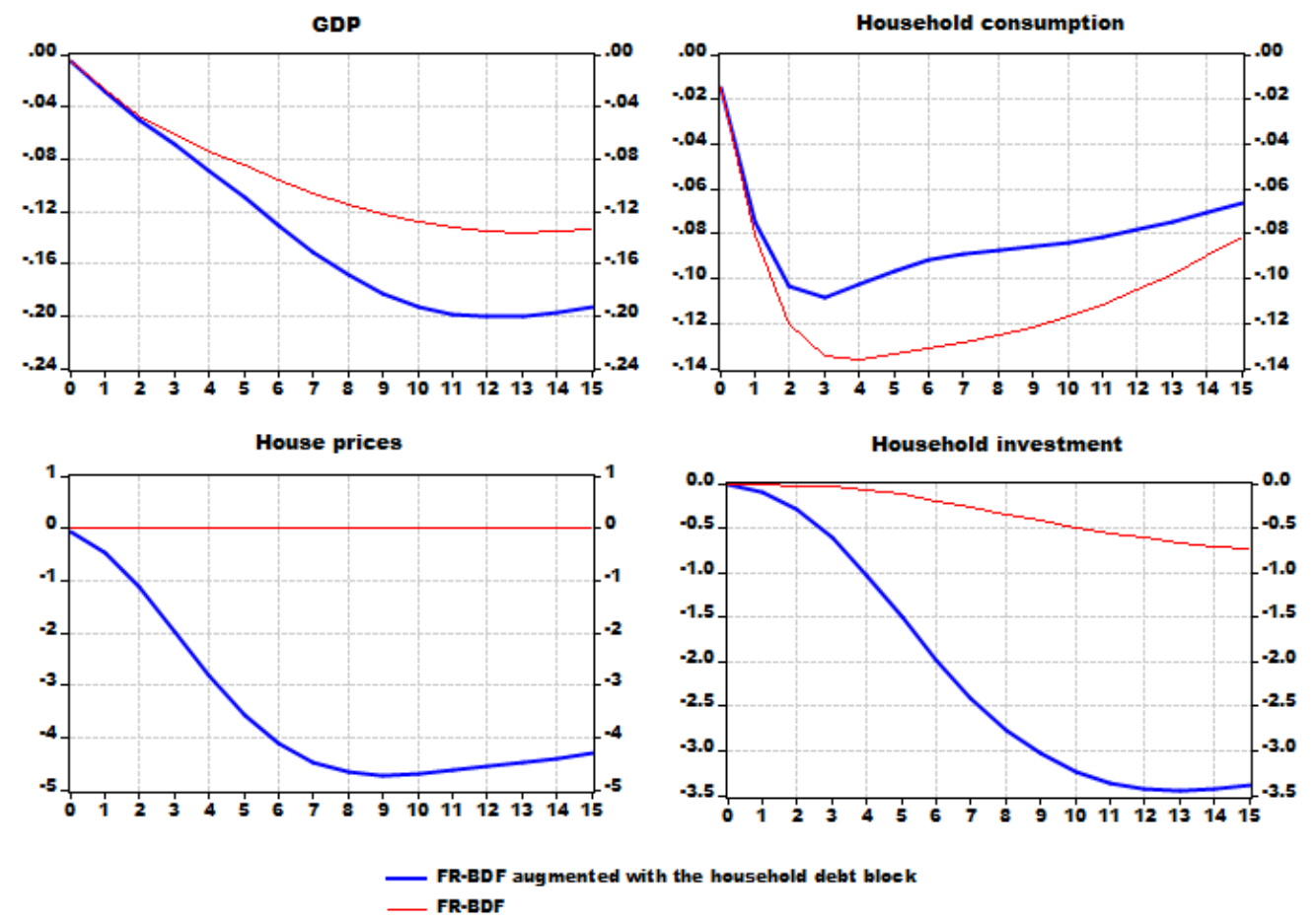

Figure 13 shows the IRF of a 4 years exogenous shock of $1 \%$ to household income. The comparison between the two models provides two pieces of information. First, the overall dynamics of the FR-BDF model are not fundamentally altered when the household credit block is included. However, the dynamics stemming from the effect of shocks on house prices, which are subsequently transmitted to household investment, reinforce the model's overall response to exogenous shocks via the macro-financial transmission mechanisms. More generally, the addition of the household credit block amplifies the response of the FR-BDF model to demand shocks via the real interest rate channel. Indeed, a demand shock has a short-term upward impact on activity and realized inflation, but also on inflation expectations 5 , The latter push the real interest rate down, which amplifies

\footnotetext{
${ }^{15}$ See Aldama and Ouvrard (2020) for more details on demand shocks in FR-BDF.
} 
the impact of the demand shock on credit and property prices, and thus on household investment (which depends positively on property prices) and activity.

Figure 13: IRF of a $1 \%$ household income shock
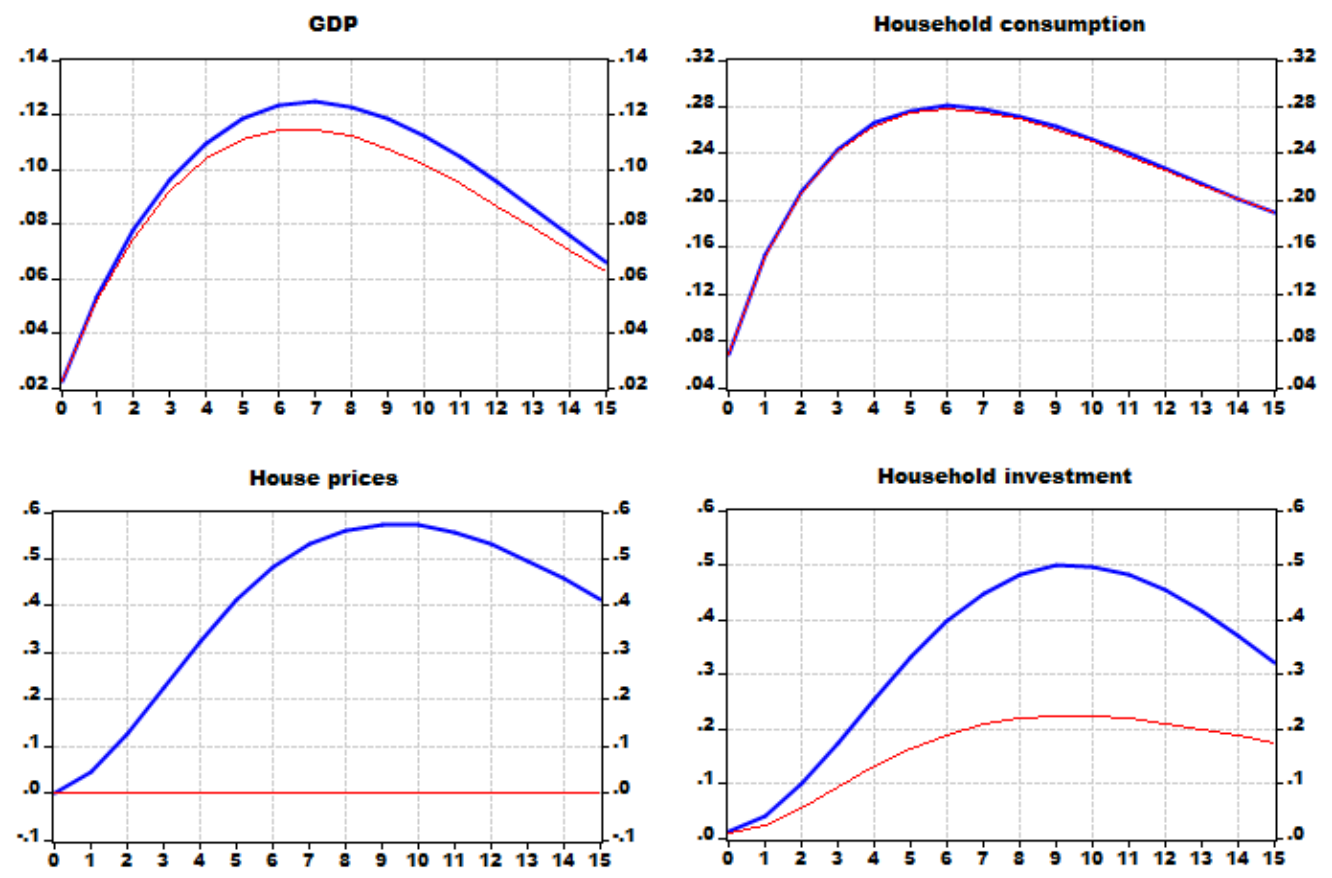

FR-BDF augmented with the hou sehold de bt block
FR-BDF

\subsection{IRFs of lending rate and house price shocks over the long run}

We now turn to the analysis of shocks that are more specific to the issue of household debt dynamics (lending rate and house price shocks). As opposed to the previous subsection, we look here only at the "augmented" model responses over a long-term horizon to study how the system comes back to its long run equilibrium and to focus on specific mechanisms that are absent of the current version of the FR-BDF model. The shock on the lending rate to households is relatively persistent (with a half-life calibrated at one year), reflecting some observed stickiness in this series, while the house price shock is supposed to be permanent.

Figure 14 shows the IRF of a 50 bp shock to the lending rate applied to household 
loan $\sqrt{16}$. This shock has a huge and rapid impact on new housing loans (peak impact of $-16 \%$ ), which is reflected in property prices and total household indebtedness. This instantaneous effect is related to the direct impact of lending rates on household demand for loans. Quite quickly however, the debt service ratio plays its stabilising role. As the weight of interest and loan repayment charges in the household budget declines to a trough after a few quarters, the risk of default on loans decreases and households once again find it easier to obtain new loans. New loans recover and even rise above the baseline before starting to converge after five years.

Figure 14: IRF of a 50bp lending rate shock
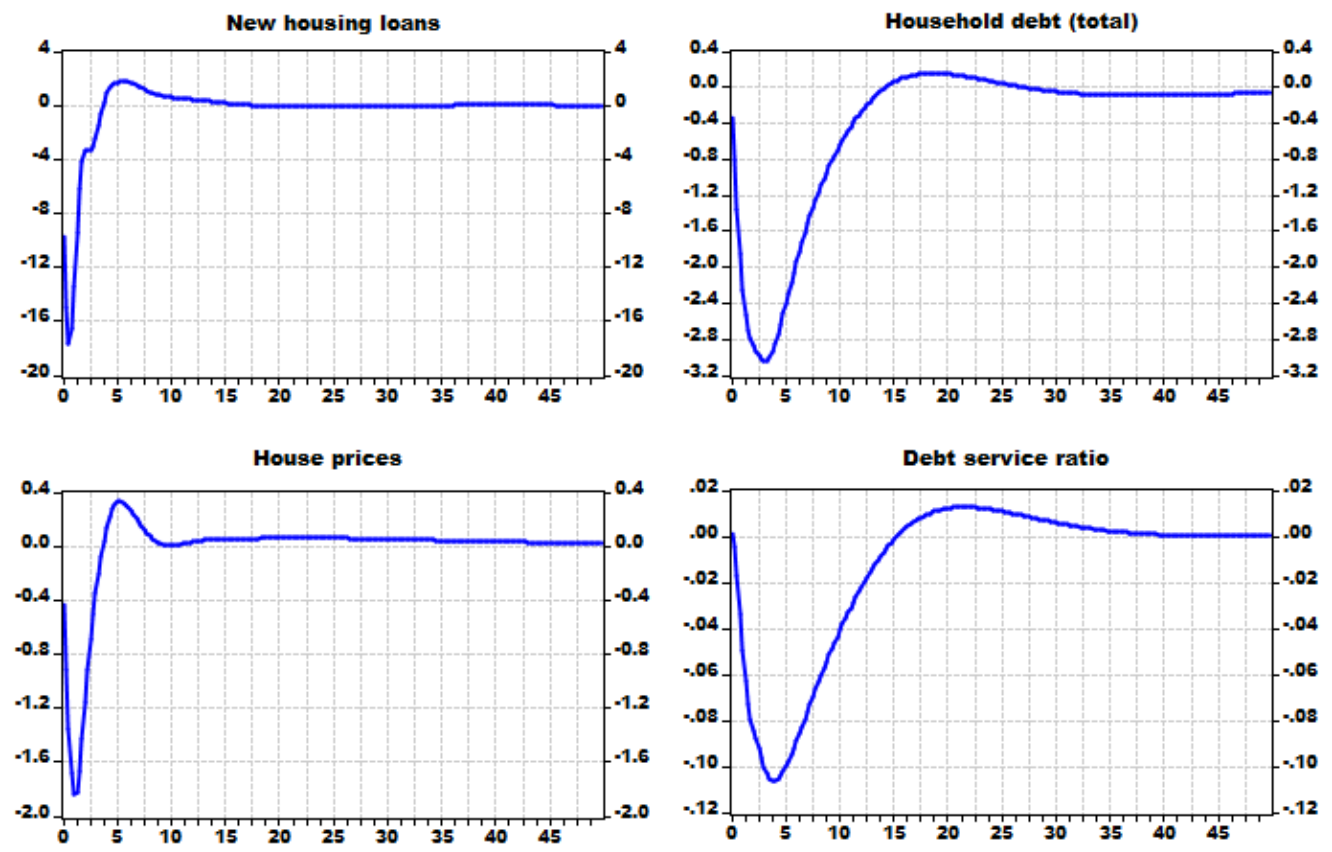

Figure 20 in Appendix E shows the IRF of a 1\% exogenous shock to household income that progressively vanishes. ${ }^{17}$. Households see an improvement in their DSR that allows them to obtain more credit. The resulting surge in new house loans is accompanied by an increase in house prices with a peak impact after 2 years. As for the lending rate shock, the DSR variable determines the long-term cyclical movements that allow the system to

\footnotetext{
${ }^{16}$ Only results for credit and house prices - the central variables of our model - are shown here. Figure 19 in the appendix shows the IRF of GDP and other macro variables (inflation, household investment and consumption).

${ }^{17}$ This shock is a bit different from the shock in the previous subsection where it was kept constant during 4 years. The point here is to focus on the stabilizing properties of the model following a shock that disappears over time.
} 
return to equilibrium. Indeed, the accumulation of new loans exerts upward pressures on the DSR. This results in higher constraints for households to obtain loans. Once a certain threshold is reached, the high DSR causes a reversal in the production of new loans, leading with a time lag to a decline in outstanding debt and in the DSR itself. This turnaround causes a reversal in property prices, which, like new loans, even falls below its baseline level for a certain period before slowly converging towards equilibrium. The dynamics towards equilibrating household indebtedness goes therefore both through the DSR and house prices.

The same mechanisms are at work following a house price shock (see Figure 15): the increase in house prices has a direct impact on the long-term target for new credit (see Equation 2.7). This direct effect then disappears once the DSR reaches a critical level at which households are forced to reduce their debt burden and house prices start to decline.

Figure 15: IRF of a $1 \%$ house price shock
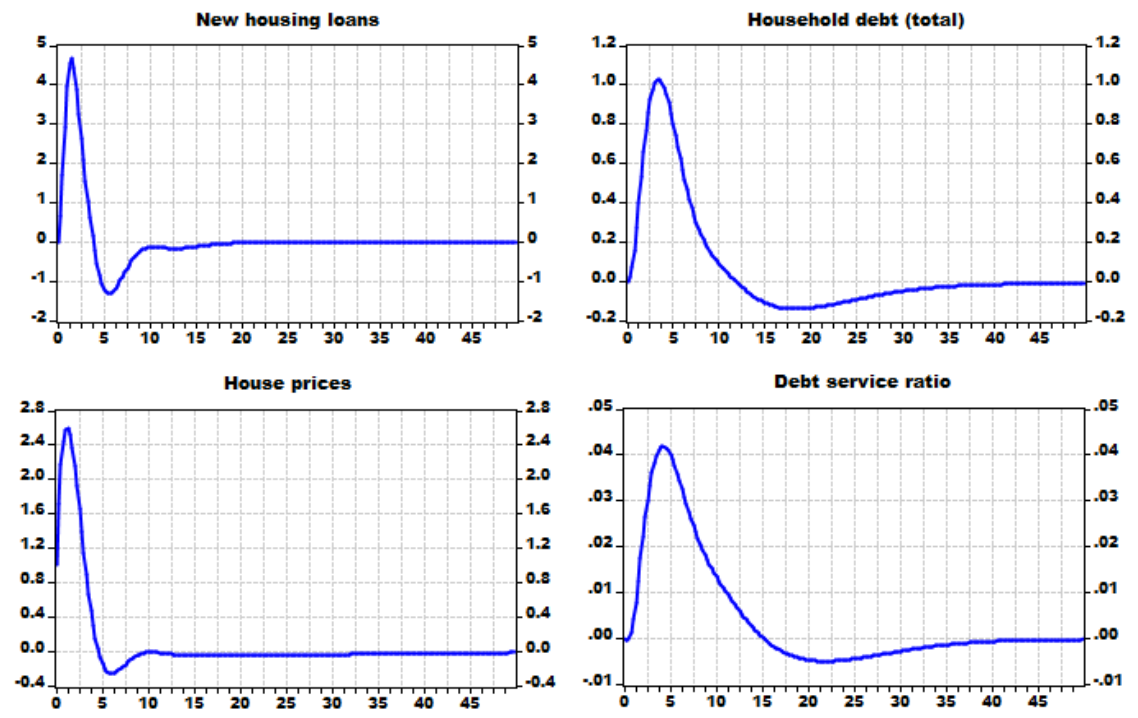

\subsection{IRFs of shocks to borrower-based measures}

In this final subsection, we study the model responses to shocks related to borrower-based measures: a decrease in loan maturity and tighter constraints on the DSR (mimicking a decrease in the cap to DSTI, i.e. the granular version of the DSR at the household level). These two shocks aim at quantifying two of the main recommendations of the HCSF (Haut conseil de stabilité financière) in 2019 to implement some "best practices" 
applicable to household property loans (maximum DSTI ratio of 33\%, loan maturity less than 25 years).

Figure 16 shows the response of the model following a decrease of 2 years in the average maturity of new housing loans. The loan maturity is an important variable of our model since it enters the amortisation rate of the outstanding amount of debt (through Equation 2.5). At first glance the results seem a bit counter-intuitive as the decrease in maturity, which corresponds to a tightening of credit conditions, leads to an increase of new housing loans in the long run. At the same time however the impact on total household debt is strongly negative. The reason behind these results is the way in which maturity enters the model. A decrease in maturity is equivalent to an increase in the amortization rate, i.e. the speed at which household debt is depleted and needs to be refuelled with new loans. Here again the dynamics are reflected in the evolution of the DSR. On impact the DSR goes up because the new loans, although lower, trigger larger repayments as their amortization is larger. Over time the effect of shorter maturities on repayments outweighs the effect on new loans, so that the overall impact of the shock on the total stock of debt and on the DSR is clearly negative. From a policy perspective, a decrease in the average maturity leads to a reduction in financial vulnerability (as measured by household indebtedness or the DSR), while it has limited implications on the business cycle owing to the small impact on both new loans and house prices. GDP (not shown here) remains almost unchanged.

Figure 16: IRF of a 2 years maturity shock
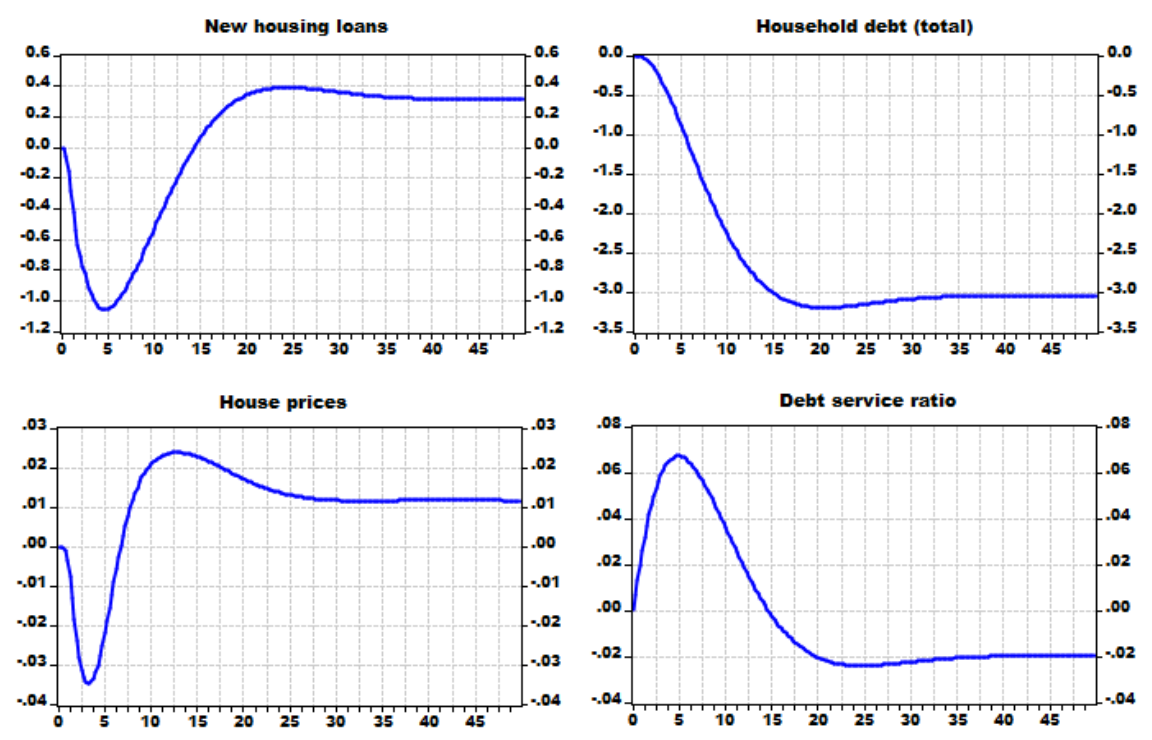
Finally, Figure 17 shows the response of the model when we arbitrarily force the DSR to stabilize at a value $0.5 \mathrm{pt}$ below its baseline. This shock is equivalent to a tightening in the DSTI ratio. We can see from the figure that this new constraint on the DSR makes it possible to impose fairly drastic quantitative restrictions on the credit supply from banks, which are obliged to select loan applications that meet the new DSTI ratio requirement. The adjustment in new loans is transmitted in the short term on the house price, which also undergoes a significant correction before stabilising in the longer term in relation to its macroeconomic determinants (income to housing capital ratio and user cost of housing capital).

Figure 17: IRF of quantitative restrictions on loan origination to fulfill tighter DSTI ratio requirements (through a $0.5 \mathrm{pt}$ decrease in the DSR)
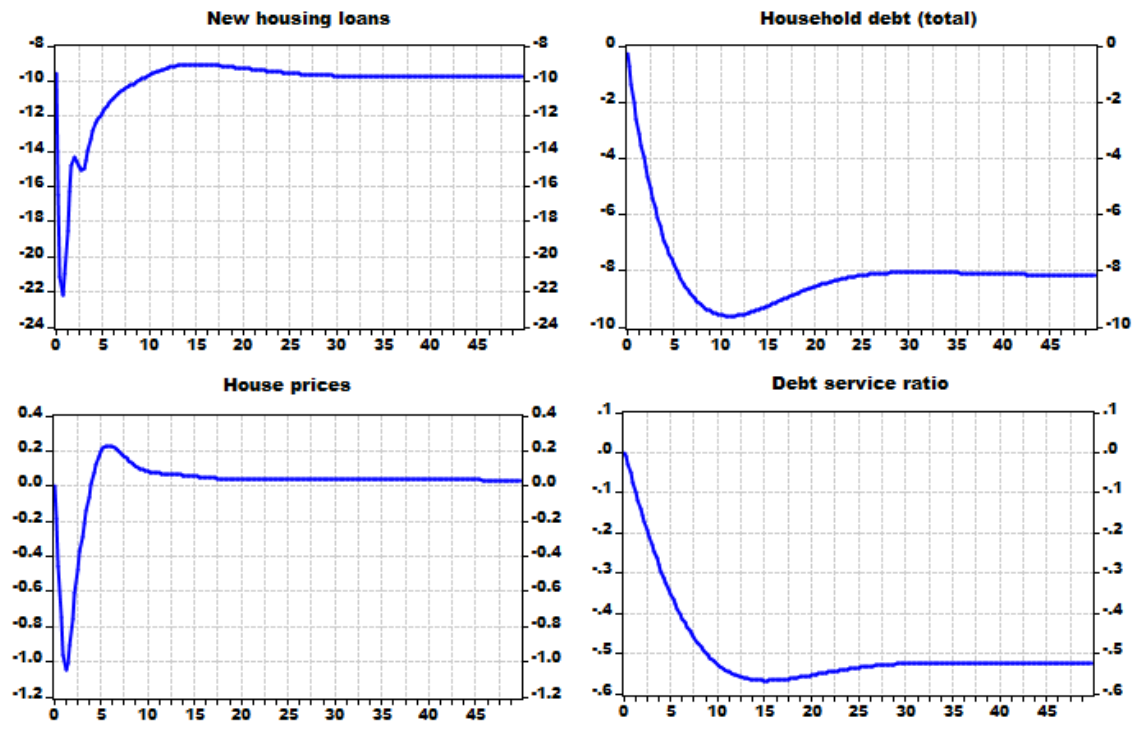

Overall, according to our model, policy measures aimed at limiting excessive risktaking behaviours by banks on the mortgage market are indeed successful in stabilising household indebtedness and the level of property prices. Moreover, the model shows that, while macroprudential measures targeting households' indebtedness are helpful to moderate the financial cycle, they have limited impacts on the business cycle as the borrower-based measures trigger minor changes at macroeconomic level. 


\section{Concluding remarks}

This paper presents a model of house prices and household indebtedness dynamics that is integrated in a broad semi-structural macroeconomic model. The resulting augmented model gives interesting results that are potentially useful as part of a central bank's toolkit. First, we have shown that the forecasting performance of the model is improved when accounting for housing market and household financial variables. Second, the policy experiments are enriched by the real-financial linkages related to household indebtedness. Finally, the model can be used to assess the role of macroprudential policies and their implications on macro-financial variables at aggregate level.

A number of limitations must be nevertheless acknowledged. First, the supply constraints coming from the banking system are implicit in the financial vulnerability indicator included in the loan origination equation. However, a richer model could explicitly account for the banking sector, allowing to study issues coming not only from the borrowers but also from the lenders. Second, accounting for household borrower riskiness at aggregate level may be seen as a simplification and introducing heterogeneity in household financial conditions and behaviours may be necessary. Households could then be distinguished according to whether they are savers or borrowers and, among the borrowers, according to their level of riskiness (measured for instance by their loan-to-value ratio). While such features have been introduced in some DSGE models (see e.g. Iacoviello and Neri (2010) ), they are still ignored in semi-structural models mainly for practical reasons. Other types of heterogeneity, such as differences in housing market trends between urban and non-urban areas or across regions, are also ignored for similar reasons.

Despite such limitations, our approach has been able to account for a number of key macro-financial channels that play a role in household finance. In the context of the Covid-19 crisis, the model appears particularly suitable to forecast credit and house price dynamics following large-scale shocks to activity and prices. Moreover, our financial vulnerability indicator (the DSR) has been shown to play a key role in the household loan dynamics and in the transmission of borrower-based policy measures to mortgage-related financial cycles. Against this background, our approach could be used to assess the impact of fiscal measures to support household income or moratoria on loan repayments as mitigation actions during crisis periods. To further explore the role of such macrofinancial mechanisms in household finance, the role of house price changes in the valuation of household wealth and their implications on the value of assets to be pledged as collateral could also be explicitly introduced in the model. As these features are less prominent in 
the case of France compared to countries like the U.S. or the U.K., this has been left for future research. 


\section{References}

Adalid, R. and Falagiarda, M. (2018). How repayments manipulate our perceptions about loan dynamics after a boom. ECB Working Paper Series, 2211.

Aldama, P. and Ouvrard, J.-F. (2020). Basic Model Elasticities of the Macroeconomic Model for France of the Banque de France (FR-BDF). Banque de France Working Paper Series, 750.

Angelini, E., Bokan, N., Christoffel, K., Ciccarelli, M., and Zimic, S. (2019). Introducing ECB-BASE: The blueprint of the new ECB semi-structural model for the euro area. ECB Working Paper Series, 2315.

Banque de France (2019). Assessment of risks to the french financial system. Technical report.

Berben, R.-P., Kearney, I., and Vermeulen, R. (2018). DELFI 2.0, DNB's Macroeconomic Policy Model of the Netherlands. DNB Occasional Studies, 1605.

Chauvin, V. and Muellbauer, J. (2018). Consumption, household portfolios and the housing market in france. Economics and Statistics, 500-501-502:151-178.

Chen, K. C. and Chivakul, M. (2008). What Drives Household Borrowing and Credit Constraints? Evidence from Bosnia and Herzegovina. IMF Working Paper, 202.

Dujardin, M., Kelber, A., and Lalliard, A. (2015). Surévaluation et rentabilité des biens immobiliers en zone euro : l'apport des données en euros par mètre carré. Bulletin de la Banque de France, 199:77-88.

ECB (2010). Financial stability review. Technical report.

Friedman, M. (1957). A Theory of the Consumption Function. Princeton University Press.

Gertler, M. and Karadi, P. (2011). A model of unconventional monetary policy. Journal of Monetary Economics, 58(1):17-34.

Gertler, M. and Kiyotaki, N. (2015). Banking, Liquidity, and Bank Runs in an Infinite Horizon Economy. American Economic Review, 105(7):2011-2043. 
Gordon, M. J. (1959). Dividends, Earnings and Stock Prices. Review of Economics and Statistics, 41(2):99-105.

Gordon, M. J. and Shapiro, E. (1956). Capital Equipment Analysis: The Required Rate of Profit. Management Science, 3(1):102-110.

Haut Conseil de Stabilité Financière (2019). Assessment of risks in the residential real estate sector. Technical report.

Iacoviello, M. and Neri, S. (2010). Housing market spillovers: Evidence from an estimated dsge model. American Economic Journal: Macroeconomics, 2(2):125-64.

Kiyotaki, N. and Moore, J. (1997). Credit Cycles. Journal of Political Economy, $105(2): 211-248$.

Kydland, F. E., Rupert, P., and Sustek, R. (2012). Housing Dynamics over the Business Cycle. NBER Working Paper Series, 18432.

Lalliard, A. (2017). Détecter autrement les tensions sur le marché immobilier résidentiel. Bulletin de la Banque de France, 210:15-23.

Lemoine, M., Turunen, H., Chahad, M., Lepetit, A., Zhutova, A., Aldama, P., Clerc, P., and Laffargue, J.-P. (2019). The FR-BDF Model and an Assessment of Monetary Policy Transmission in France. Banque de France Working Paper Series, 736.

Lindé, J., Smets, F., and Wouters, R. (2016). Challenges for Central Banks' Macro Models. CEPR Discussion Papers, 11405.

Mazet-Sonilhac, C. and Mésonnier, J.-S. (2016). Le coût des capitaux propres des grandes entreprises non financières en zone euro : une évaluation sur la dernière décennie. Bulletin de la Banque de France, 207:33-46.

Modigliani, F. (1986). Life Cycle, Individual Thrift, and the Wealth of Nations. American Economic Review, 76(2):1-41.

Waldron, M. and Zampolli, F. (2010). Household debt, house prices and consumption in the United Kingdom: a quantitative theoretical analysis. Bank of England Working Paper, 379. 


\section{A Accounting method for computing mortgage debt repayments}

The first approach we considered for modelling mortgage debt repayments (called "Method 1 " in the main text) assumes that a loan is repaid at a fixed rate over a certain period of time with a constant monthly payment.

Under these conditions, the amount of a new loan granted at date $t=0$, which by definition is equal to the discounted sum of the future monthly instalments, can be written as follows:

$$
C_{0}=\sum_{t=1}^{M} \frac{P}{(1+i)^{t}}(1+i)^{t} \Longrightarrow P=\frac{i C_{0}}{1-(1+i)^{-M}}
$$

Where $P$ is the constant monthly instalment of the loan, $M$ is the maturity of the loan, $i$ is the fixed interest rate at which it was granted.

Starting from 2003 (the beginning of our series for new loans), we then consider that for each generation of new loans granted at date $v, v \in\{03 m 01, \ldots, 18 m 12\}$, all the loans of this generation have been granted at the same rate $i_{v}$ and with the same maturity $M_{v}$. The new loans of the date $v$ (i.e. $C_{v}$ ) will thus give rise to the payment of a monthly instalment $P_{v}=\frac{i_{v} C_{v}}{1-\left(1+i_{v}\right)^{-M_{v}}}$ to be paid at each future date $t \in\left[v+1, v+M_{v}\right]$. Thus, for each generation of credits granted in $v$ :

$$
\left\{\begin{array}{l}
R_{v t}=P_{v}-i_{v} C_{v, t-1} \\
C_{v t}=C_{v, t-1}-R_{v t}
\end{array} \quad t \in\left[v+1, v+M_{v}\right]\right.
$$

With $R_{v t}$ the principal repayment amount at date $t, i_{v} C_{v, t-1}$ the interest repaid at date $t, C_{v t}$ the amount of credit remaining to be repaid at date $t$.

If we take the example of a loan of $€ 100,000$, granted on 1 January 2018 at an annualized interest rate of $2 \%$ and for a maturity of 20 years, Figure 18 gives the repayment schedule of the principal and the interest charge, as well as the amortization rate (ratio of the repayment to the remaining outstanding amount) at each period over the entire maturity of the loan.

The repayment at date $\mathrm{t}$ of all the loans granted in the past and still being repaid is equal to the sum of the repayments $R_{v t}$ of all past generations of loans such that:

$$
R_{t}=\sum_{v \in \omega_{t}} R_{v t}, \quad \omega_{t}=\left\{v, 0 \leq t-v \leq M_{v}\right\}
$$


Figure 18: Simulation of a loan of $€ 100,000$ granted on 1 Jan. 2018
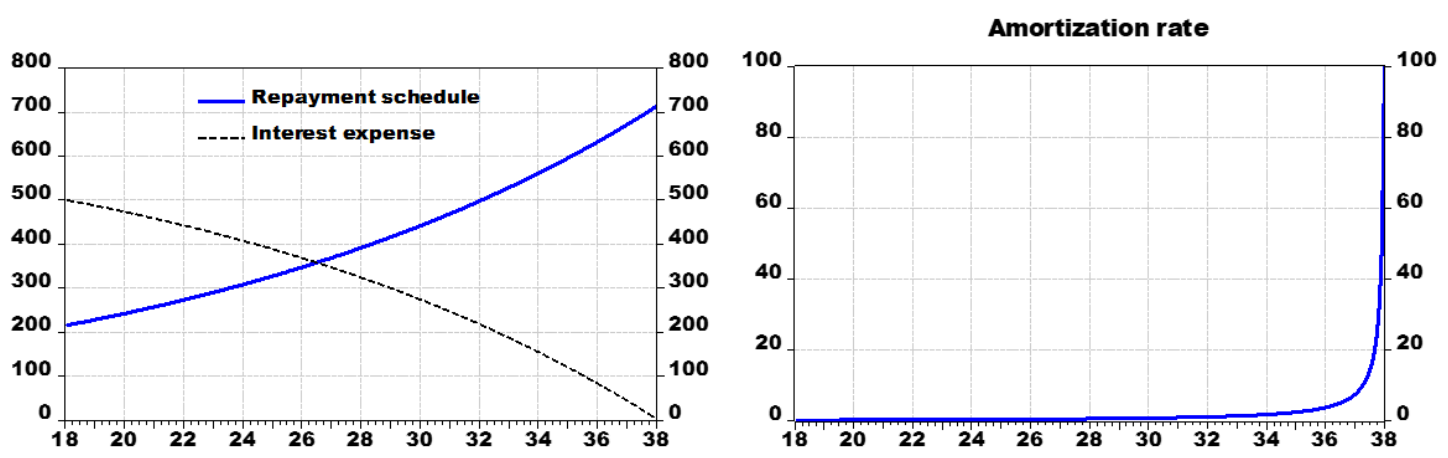

Note: The repayment schedule, interest expense and amortization rate are computed under the assumption of an annual interest rate of $2 \%$ and a maturity of 20 years.

\section{B Data Sources}

Table 6 shows the available series from the BSI (balance sheet items) database. Flows of housing loans to individuals, which form the core of our analysis, account for $90 \%$ of the flows of housing loans to households + NPISHs (non-profit institutions serving households) and for around $80 \%$ of total flows of loans to households + NPISHs. Data on new housing loans to individuals has been available since Q1 2003 and come from a different base (MIR base). Repayments are not published but can be derived from the difference between loan flows and new loans. Average duration of loans is retropolated before 2004 with the series used by Adalid and Falagiarda (2018) from the Household Finance and Consumption Survey (HCFS). 
Table 6: Statistical sources

\begin{tabular}{|c|c|c|}
\hline Variable name & BSI codes & Availability \\
\hline $\begin{array}{c}\text { Flows of mortgage loans } \\
\text { to individuals (new loans - repayments) }\end{array}$ & M.FR.Y.R.A220Z.A.4.U6.2254FR.Z01.E & Since May 1993 \\
\hline New housing loans for individuals & M.FR.B.A22.A.5.A.2254U6.EUR.N & Since Jan. 2003 \\
\hline $\begin{array}{c}\text { Share of renegotiations in new } \\
\text { mortgage loans to individuals }\end{array}$ & M.FR.B.A22PR.A.W.A.2254FR.EUR.N & $\begin{array}{c}\text { Monthly since Dec. 2014 } \\
\text { Quarterly since 2010Q3 }\end{array}$ \\
\hline $\begin{array}{c}\text { Interest rate for housing loans } \\
\text { with maturity of over 1 year }\end{array}$ & M.FR.B.A2C.K.R.A.2250.EUR.N & Monthly since Jan. 2003 \\
\hline $\begin{array}{c}\text { Average duration of housing loans } \\
\text { to individuals }\end{array}$ & Q.FR.R.A22FRX.A.D.A.2254FR.EUR.N & Quarterly since 2004Q1 \\
\hline
\end{tabular}

\section{Endogenising equity prices}

Equity prices are assumed to follow the dividend discount model à la Gordon-Shapiro (Gordon and Shapiro (1956) and Gordon (1959)). According to this standard valuation model, the price of a stock at period $t\left(P_{t}^{S}\right)$ is equal to the value of the next period's dividend $\left(D_{t+1}\right)$ divided by the difference between the cost of equity $\left(\right.$ coe $\left._{t}\right)$ and the expected growth rate of future dividends $(g)$.

$$
P_{t}^{S}=D_{t+1} /\left(\operatorname{coe}_{t}-g\right)
$$

Using the CAC40 as the composite index of equity prices, the above equation gives us the long-term target for equity prices. We use also the non-financial corporations' gross operating surplus as a proxy of dividends and the steady-state value for nominal growth rate $(2.96 \%$ in FR-BDF) as a proxy for the expected growth rate of future dividends. The cost of equity is computed internally at Banque de France, based on a methodology explained in Mazet-Sonilhac and Mésonnier (2016).

Adding short-run determinants and indicator variables, we estimate the following 
equation:

$$
\begin{array}{r}
\Delta p_{t}^{S}=\alpha^{S}+\beta^{S}\left(p_{t-1}^{S}-\left[\operatorname{gos}_{t-1}^{N F C}-\log \left(\operatorname{coe}_{t-1}-g\right)\right]\right)+\ldots \\
\ldots+\gamma_{1}^{S} \Delta p_{t-1}^{S}+\gamma_{2}^{S} \Delta g o s_{t-1}^{N F C}+\gamma_{3}^{S} \Delta \log \left(\operatorname{coe}_{t-1}-g\right)+\sum_{i=4}^{7} \gamma_{i} \operatorname{Ind}_{i}^{S}+\epsilon_{t}^{S}
\end{array}
$$

We obtain a value of $\beta^{S}$ equal to $11.4 \%$ with a adjusted R-square slightly below $60 \%$ (see table 7). This shows that the dividend discount model captures relatively well the dynamics of equity prices in France.

Table 7: Estimation results for the stock price equation

\begin{tabular}{lcc}
\hline Variable & Coefficient & Value \\
\hline Constant & $\alpha^{S}$ & $-0.82^{* * *}$ \\
Error correction term & $\beta^{S}$ & $-0.11^{* * *}$ \\
Short-term variables & & \\
$\quad \Delta p_{t-1}^{S}$ & $\gamma_{1}^{S}$ & $0.27^{* * *}$ \\
$\quad \Delta g o s_{t-1}^{N F C}$ & $\gamma_{2}^{S}$ & $1.01^{* *}$ \\
$\quad \Delta \log \left(\operatorname{coe}_{t-1}-g\right)$ & $\gamma_{3}^{S}$ & $-0.47^{* * *}$ \\
Adjusted $R^{2}$ & & 0.59 \\
\hline${ }^{* * *},{ }^{* *}$ and ${ }^{*}$ denote the $1 \%, 5 \%$ and $10 \%$ significance levels.
\end{tabular}

\section{Other equations of the model}

We present in this appendix the results for the two equations determining the apparent rates of return on household gross assets (resp. gross liabilities) for property income received (resp. paid) by households. The equations take the following form:

$$
\begin{array}{r}
\Delta i_{t}^{R}=\beta^{R}\left(\alpha_{0}^{R}+\alpha_{1}^{R} i_{t}^{10 y}+\alpha_{2}^{R} i_{t}^{3 m}-i_{t-1}^{R}\right)+\gamma_{1}^{R} \Delta i_{t-1}^{R}+\gamma_{2}^{R} \Delta i_{t}^{3 m}+\gamma_{3}^{R} \Delta \operatorname{coe}_{t-1}+\sum_{i=1}^{3} \gamma_{i+3}^{R} \operatorname{Ind} d_{i}^{R}+\epsilon_{t}^{R} \\
\Delta i_{t}^{P}=\beta^{P}\left(\alpha_{0}^{P}+\alpha_{1}^{P} i_{t}^{10 y}+\alpha_{2}^{P} i_{t}^{3 m}-i_{t-1}^{P}\right)+\gamma_{1}^{P} \Delta i_{t-1}^{P}+\gamma_{2}^{P} \Delta i_{t-2}^{P}+\gamma_{3}^{P} \Delta i_{t}^{3 m}+\gamma_{4}^{P} \operatorname{Ind}^{P}+\epsilon_{t}^{P}
\end{array}
$$

Where $i^{R}$ (resp. $i^{P}$ ) denotes the apparent rate of return on gross assets (resp. gross liabilities), $i^{10 y}$ is the 10 -year French sovereign rate, $i^{3 m}$ is the 3 -month Euribor, coe is the cost of equity, and variables denoted Ind are dummy variables. 
Table 8: Estimation results for the apparent rate of return on gross assets

\begin{tabular}{|c|c|c|}
\hline Variable & Coefficient & Value \\
\hline $\begin{array}{l}\text { Error correction term } \\
\text { Long-term variables }\end{array}$ & $\beta^{R}$ & $0.16^{* * *}$ \\
\hline $\begin{array}{l}i_{t}^{10 y} \\
i_{t}^{3 m}\end{array}$ & $\begin{array}{l}\alpha_{1}^{R} \\
\alpha_{2}^{R}\end{array}$ & $\begin{array}{r}0.22^{* * *} \\
0.17^{* *}\end{array}$ \\
\hline
\end{tabular}

Short-term variables

$\begin{array}{lcc}\Delta i_{t-1}^{R} & \gamma_{1}^{R} & 0.22^{* *} \\ \Delta i_{t}^{3 m} & \gamma_{2}^{R} & 0.05^{* *} \\ \Delta \text { coe }_{t-1} & \gamma_{3}^{R} & 0.03^{*}\end{array}$

Dummy variables

$\begin{array}{lll}06 Q 1 & \gamma_{4}^{R} & 0.001^{* * *} \\ 08 Q 1 & \gamma_{5}^{R} & 0.0003^{*} \\ 08 Q 2 & \gamma_{6}^{R} & 0.0003^{*}\end{array}$

Adjusted $R^{2} \quad 0.57$

${ }^{* * *},{ }^{* *}$ and ${ }^{*}$ denote the $1 \%, 5 \%$ and $10 \%$ significance levels.

Table 9: Estimation results for the apparent rate of return on gross liabilities

\begin{tabular}{lcc}
\hline Variable & Coefficient & Value \\
\hline $\begin{array}{l}\text { Error correction term } \\
\text { Long-term variables }\end{array}$ & $\beta^{P}$ & $0.08^{* * *}$ \\
$\quad i_{t}^{10 y}$ & $\alpha_{1}^{P}$ & $0.36^{* *}$ \\
$\quad i_{t}^{3 m}$ & $\alpha_{2}^{P}$ & $0.34^{* *}$ \\
Short-term variables & & \\
$\Delta i_{t-1}^{P}$ & $\gamma_{1}^{P}$ & $1.01^{* *}$ \\
$\Delta i_{t-2}^{P}$ & $\gamma_{2}^{P}$ & $-0.30^{* *}$ \\
$\Delta i_{t}^{3 m}$ & $\gamma_{3}^{P}$ & $0.09^{* *}$ \\
Dummy variables & & \\
$08 Q 1$ & $\gamma_{4}^{P}$ & $0.0003^{* *}$ \\
Adjusted $R^{2}$ & & 0.89 \\
\hline *** ${ }^{* *}$ and ${ }^{*}$ denote the $1 \%, 5 \%$ and $10 \%$ significance levels.
\end{tabular}




\section{E Other charts}

Figure 19: IRF to a 50bp lending rate shock
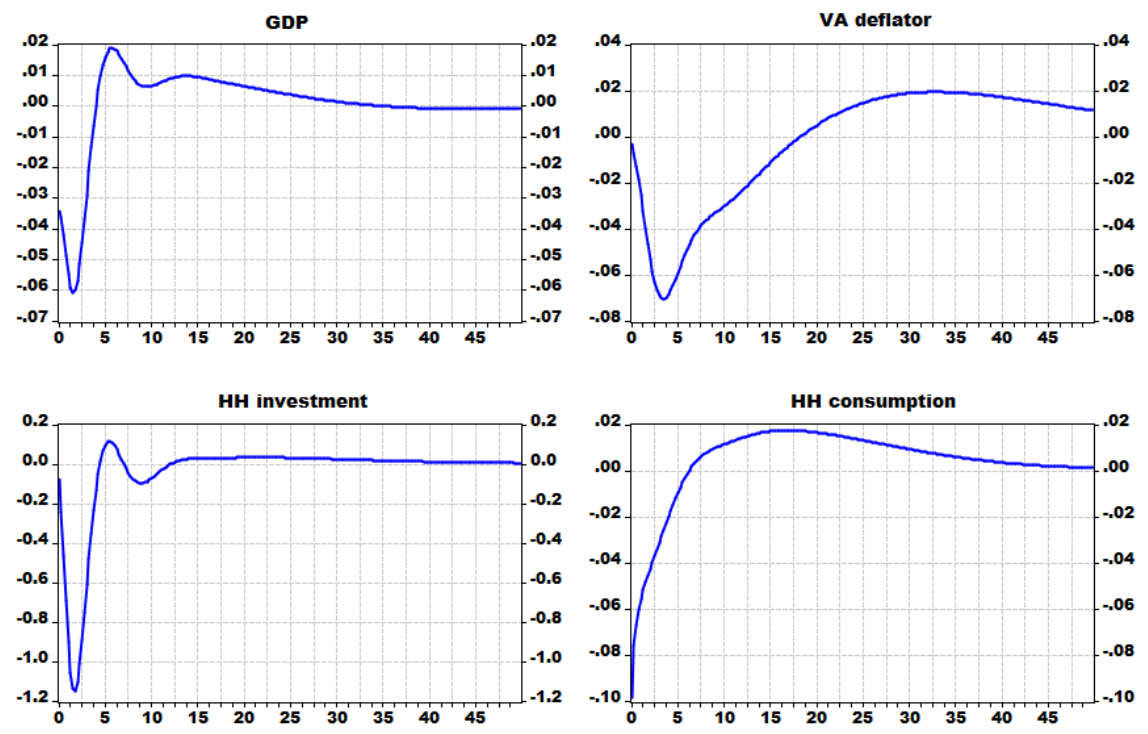
Figure 20: IRF to a $1 \%$ household income shock
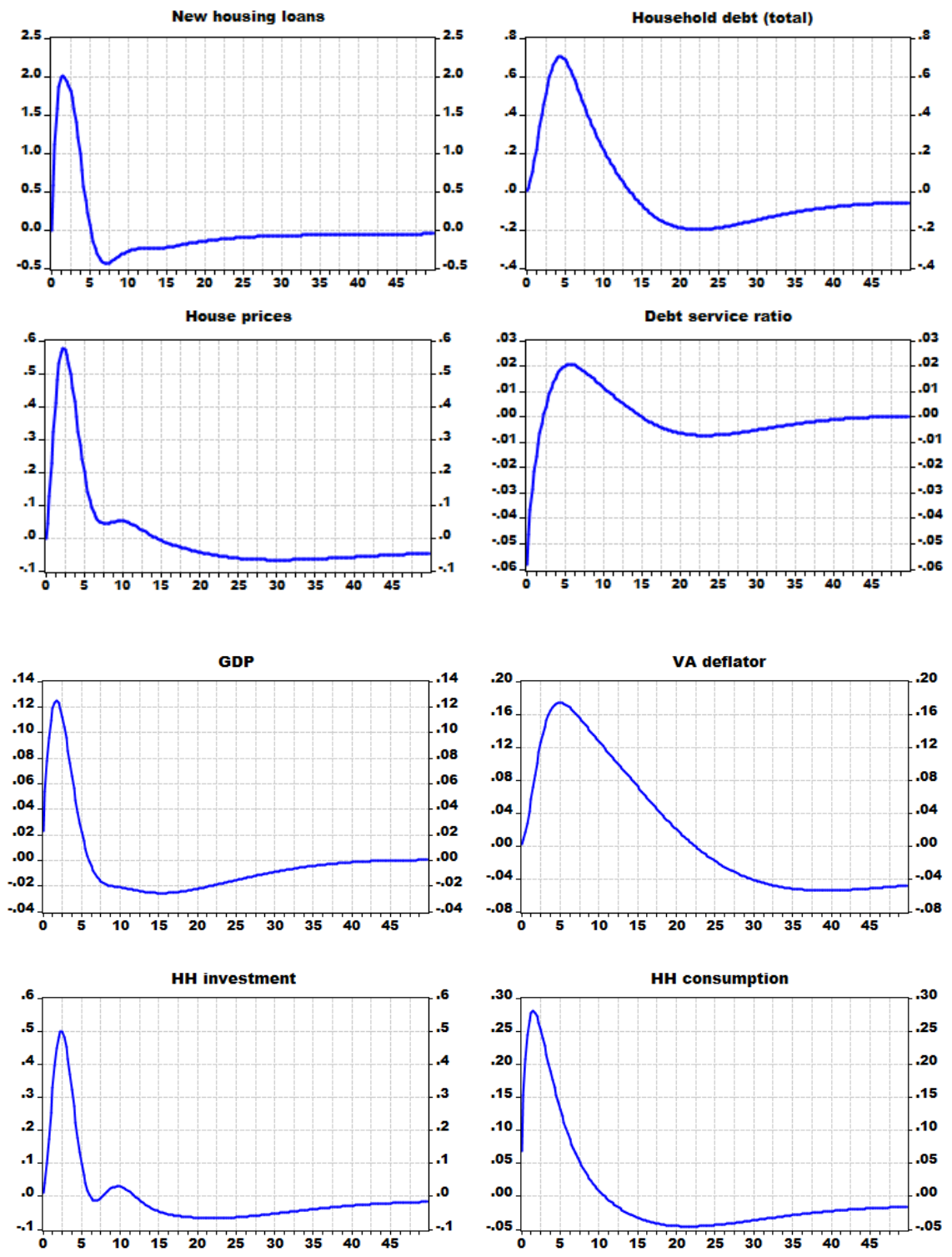
Figure 21: IRF of a $1 \%$ house price shock
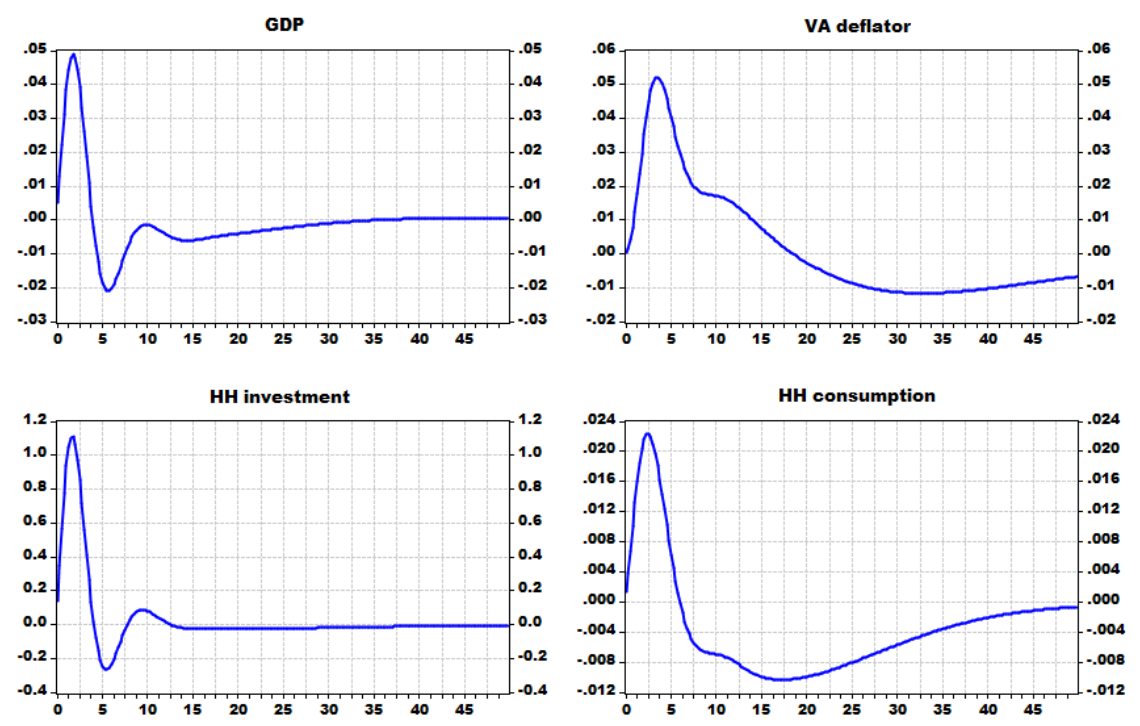

Figure 22: IRF of a 2 years maturity shock
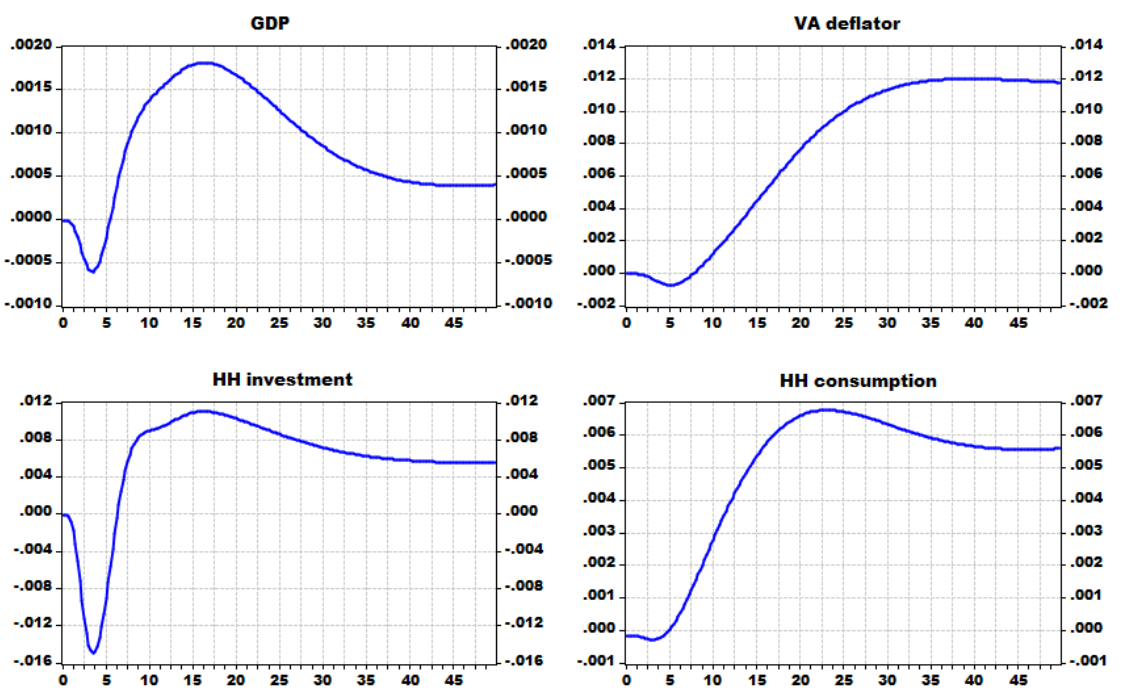
Figure 23: IRF of quantitative restrictions on loan origination to fulfill tighter DSTI ratio requirements (through a 0.5 pt decrease in the DSR)
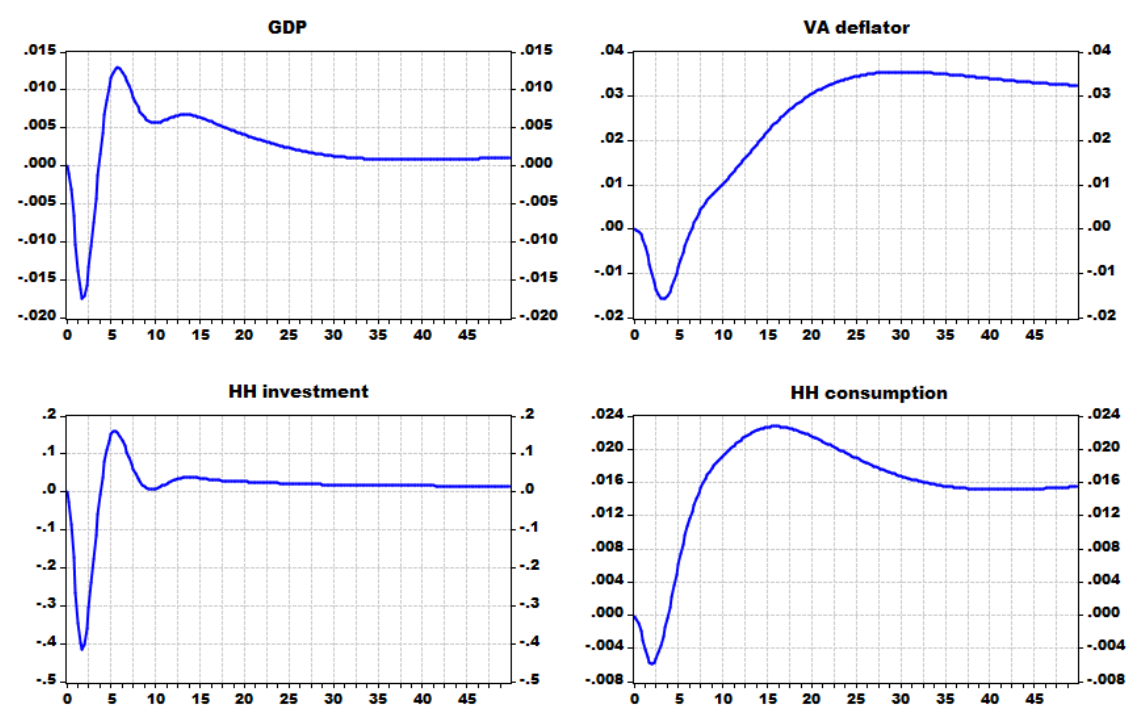